\title{
The Determination of the Intellectual Equipment Is Imperative: Mental Hygiene, Problem Children, and the History of the Provincial Child Guidance Clinic of British Columbia, 1932-1958
}

\author{
Gerald Thomson
}

\section{ABSTRACT}

The founding in 1932 of British Columbia's provincial Child Guidance Clinic by Dr. A. L. Crease of Essondale Mental Hospital was seen as a medically progressive measure in the preventive work to stem mental ailments in children and prevent future adult mental illness. The clinic's history and the influence of mental hygiene on early twentieth-century medical, educational, and social service agencies in BC that dealt with so-called "problem children" has received limited scholarly attention. This paper argues that the mental hygiene agenda was cultivated by psychiatrists working at mental asylums, teachers of "subnormal" children, child welfare advocates, and university-trained social workers, all of whom increasingly shaped child-saving policy in British Columbia. However, from its beginnings, the British Columbia provincial Child Guidance Clinic had an unstable clinical history and it was completely reorganized in 1946 and subsequently closed in 1958. The clinic's history stood in stark contrast to Alberta's child guidance clinics, which applied a rigid mental hygiene policy of eugenic sterilization until the early 1970s. This significant difference indicates the need for other detailed microhistories of child psychiatry and child guidance clinics across Canada.

\section{RÉSUMÉ}

La fondation de la clinique provinciale Child Guidance Clinic à l'hôpital psychiatrique d'Essondale en Colombie-Britannique par le docteur A. L. Crease en 1932 a été considérée comme une mesure médicale progressiste misant sur le travail préventif afin d'enrayer les maladies mentales chez les enfants et de prévenir les maladies mentales des adultes. L'histoire de la clinique et l'influence de l'hygiène mentale sur les agences médicales, éducatives, et de services sociaux qui s'occupaient des soi-disant " enfants à problèmes " en Colombie-Britannique au début du vingtième siècle n'a pourtant que très peu retenu l'attention des chercheurs. Cet article démontre que le programme d'hygiène mentale développé par des psychiatres travaillant dans des asiles psychiatriques, des enseignants pour enfants " retardés ", des défenseurs du bien-être de l'enfant et des travailleurs sociaux formés à l'université a largement façonné la politique de protection de l'enfance en Colombie-Britannique. La Child Guidance Clinic a toutefois été 
marquée par des antécédents cliniques instables depuis ses débuts, et a été complètement réorganisée en 1946, avant d'être fermée en 1958. L'histoire de cette clinique contraste nettement avec les cliniques d'orientation pédiatrique de l'Alberta, qui appliquaient une stricte politique d'hygiène mentale de stérilisation eugénique jusqu'au début des années 1970. Cette différence significative démontre qu'il est nécessaire de mener d'autres microhistoires détaillées sur les cliniques de psychiatrie infantile et d'aide à l'enfance au Canada.

\section{Introduction: Mental Hygiene and Child Guidance}

Shortly after the twentieth century began, a book was published that made an impassioned plea for reshaping social attitudes towards education and child rearing. Ellen Key's The Century of the Child appeared in English in 1909 after first being published in Swedish in 1900. Key stressed that children were individuals who needed to develop a sense of personal freedom through learning. She described traditional schooling as murdering the souls of children. Key's work had a profound international impact stressing the cooperative role of families and schools in educating children. ${ }^{1}$ In contrast Progressives in North America saw a need to manage children according to scientific principles to assure social stability. Their alarmist stance was stimulated by high levels of urban child poverty and crime among so called delinquents along with a perceived need to isolate all children deemed mentally deficient. ${ }^{2}$ Theresa Richardson titled her 1989 history of the mental hygiene movement in North America after Key's seminal work. Her book, The Century of the Child, sought to show when professionals in medicine, social work, and education adopted the "childhood gaze" through which the "mental hygiene of childhood came to be viewed as a path to social salvation" for Progressives. According to Richardson, it was "child guidance which legitimated the classification of mentally disordered children and substantially contributed to the formalization of child psychiatry." 3

In this paper, I argue that an emerging mental hygiene agenda shaped various initiatives to deal with problem children in early twentieth-century British Columbia. This agenda culminated in the creation of the provincial Child Guidance Clinic in 1932. The program of this clinic until its closure in 1958 did not resemble the activist eugenic program of Alberta's child guidance clinics. Although British Columbia was the only Canadian province besides Alberta to pass a sterilization law, the application of mental hygiene through the child guidance clinics was vastly different in each province.

According to Richardson, child guidance clinics were "a unique American contribution to the history of child psychiatry." "The mental hygiene approach was rooted in eugenics, which maintained that problem children were the biological result of mentally defective parents with inferior "germ plasm." ${ }^{5}$ Psychiatrist William Healy pioneered a therapeutic team approach at the Juvenile Psychopathic Institute of Chicago beginning in 1909. Healy's progressive, rehabilitative, child-saving work was noticed by the Commonwealth Fund of the Rockefeller Foundation, which sponsored the Program for the Prevention of Juvenile Delinquency and acted to dispense seed money for the creation of child guidance clinics in North America from the 
1920s until the 1930s. ${ }^{6}$ The history of American child guidance clinics has been well documented. Sol Cohen first traced the spread of mental hygiene into the public schools through the Commonwealth Fund's child health programs. ${ }^{7}$ Margo Horn examined the evolution of the Philadelphia Child Guidance Clinic over two decades from 1922 to $1944 .{ }^{8}$ Kathleen Jones conducted an in-depth study of Boston's Judge Baker Guidance Center for Children for the period 1920-45. ' Theresa Richardson in her study of the mental hygiene movement and social policy in North America devoted a chapter to the medicalization of mental hygiene practice in the clinics. ${ }^{10}$ There was a movement away from humane child therapy as the clinics shifted focus by the late 1920s and concentrated on the maladjustment of individual children. ${ }^{11}$ In Canada, hereditarianism was the prevailing orthodoxy of the Canadian National Committee for Mental Hygiene (CNCMH). The first children's clinic was opened in April 1914 at Toronto's General Hospital by doctors C. K. Clarke, Oswald C. J. Withrow, and Clarence M. Hincks. ${ }^{12}$ By 1923, Clarke believed "the clinic has become a powerful factor in the control of juvenile criminality and prostitution, as well as the education of the public to the modern attitude of medicine." ${ }^{13}$ Across Canada, child guidance clinics were created with help from Rockefeller funds. In 1919, a provincial clinic opened in Winnipeg, Manitoba, and by 1929, Alberta had clinics in Edmonton, Calgary, and Lethbridge. By 1930, Ontario had clinics in Toronto, Brockville, Hamilton, Kingston, and London. Hincks boldly proclaimed that these child guidance clinics seemed destined to prevent serious mental disorders among Canada's youth. ${ }^{14}$ Eugenic theories persisted in Canada long after they had been robustly challenged in the United States by behavioural and environmental theories. ${ }^{15}$

Amy Samson is the author of the only in-depth historical examination of child guidance clinics in Canada. Her work on Alberta's child guidance clinics shows how hereditarianism dominated clinical practice, and she exposes the clinic's role in facilitating sterilization for the Alberta Eugenics Board. Her research shows that "Alberta's guidance clinics extended the reach of the eugenic sterilization program, as well as its presence in the community." While claiming to help individual children adjust to their social surroundings and prevent serious mental illness, the clinics recommended "sterilization and supervision," "surgical treatment," "special class[es] at school," and "institutionalization training and care." Without the meticulous casework of nurses, social workers, and psychiatrists working in concert with educators, public health nurses, juvenile social workers, and juvenile courts, Alberta's program of sterilization would not have been feasible. Samson concludes "these professions, each in various ways, formed integral parts of the province's sterilization bureaucracy." By the late 1940s, the clinic coordinated the work of "visiting teachers" and public health nurses who made 439 "Mental Hygiene Home Visits" between 1949 and $1953 .{ }^{16}$ The history of the eugenics apparatus in Alberta is well documented in the historical literature as is the political support it received from the United Farmers Party, and later, the Social Credit party. ${ }^{17}$ What came to light in Samson's work was the major role the child guidance clinics played in that history. Samson herself drew on the work of Donald Elroy Orn, who interviewed staff at the child guidance clinic in Edmonton in the late 1960s. ${ }^{18}$ 


\section{Mental Hygiene and "Problem" Children in British Columbia}

In British Columbia, "problem children” apprehended for criminal acts were sent to jail with adults but were housed separately. ${ }^{19}$ Only boys were sent to jail; girls were dealt with by their parents or placed in a charity home. In 1890, a Reformatory Act was passed for boys sixteen years and under who were to be sentenced to a purposebuilt juvenile reformatory. ${ }^{20}$ After a troubled start, the Victoria Juvenile Reformatory was re-opened in 1898 under Acting Superintendent R. E. Hanson. It was located adjacent to the Victoria Gaol, and most boys had been incarcerated for burglary and stealing; the reformatory was always filled to capacity. ${ }^{21}$ Children with physical/mental problems were cared for by their parents and extended families or they were sent to a charity home, if possible. Some church charities, such as the Protestant orphan's home in Victoria, refused to take "delinquents," "defectives," and children "with serious social problems." ${ }^{22}$ Neglected children were an increasing urban problem in British Columbia in the late nineteenth century and, due to the lobbying efforts of Vancouver's League of Women, the province passed a Child Welfare Act in 1901 and created the Children's Aid Society in 1902. British Columbia was following Ontario's lead; Ontario had established children's aid societies in 1891 and passed a Children's Protection Act in $1893 .{ }^{23}$ British Columbia passed its own Children's Protection Act in 1903, used principally by social workers of the Children's Aid Society when families proved uncooperative. Children who ran afoul of the law were specifically dealt with by the Juvenile Delinquents and Courts Act of $1908 .^{24}$ In 1910 , the first juvenile court opened in Vancouver, while outside urban areas, adult courts dealt with juvenile offenders. ${ }^{25}$ The 1905 opening of the Vancouver Boys' Industrial School and in 1914 the Girls' Industrial School, also in Vancouver, created custodial facilities for such problem children. Building Industrial schools to reform wayward youth was part of a "discernable cyclical pattern" that began in the Victorian era and would come to an end by the mid to late twentieth century according to Paul W. Bennett. ${ }^{26}$

According to Neil Sutherland, "by the early 1920's, British Columbia had enacted enough legislation affecting children and parents to provide a legal framework" for the control of problem children. Sutherland saw the main thrust of this progressive child reform movement as centred in public health initiatives. This public health movement comprised health professionals, community and women's groups, and some members of local school boards, along with boards of health. Sutherland mentions the expansion of public health nursing services, well baby clinics, school health education, distribution of free health pamphlets by the provincial health department, and vaccination campaigns. ${ }^{27}$ Mona Gleason cites eugenics as influencing numerous child health and welfare initiatives in English Canada. ${ }^{28}$ Leading child health experts saw delinquency as yet another manifestation of feeble-mindedness. ${ }^{29}$ Medical doctors involved in school health inspections and asylum doctors at the Public Hospital for the Insane (PHI) in New Westminster and the Essondale asylum colony in Coquitlam also helped advance this mental hygiene agenda as a way to deal with "problem children" and mentally ill adults.

The child-saving efforts of women's groups and children's charities in the province 
were increasingly influenced by the mental hygiene agenda. Diane Matters examined juvenile delinquency in Vancouver from 1910 to 1915 and found that environmental arguments about poor social backgrounds seemed to define the debate, but after the First World War, "the mental hygiene movement . . . came to dominate discussion of the problem." ${ }^{30}$ This was evident in a speech on "Community Control of the Feebleminded" given by Vancouver's first school psychologist, Martha Lindley, at the 1918 inaugural convention of the Provincial Child Welfare Association of British Columbia. Lindley, trained by Henry Herbert Goddard at the Vineland Training School, stressed the need for close community monitoring of feeble-minded children. ${ }^{31}$ The adoption of mental hygiene as an integral part of child-saving can be seen as early as 1903 when the upkeep of a six-year-old boy committed to the PHI in New Westminster was paid for by the Children's Aid Society. In 1920, a rural Revelstoke school inspector, A. Miller, had to appeal directly to the provincial secretary's office to place a girl in the PHI when her recently widowed mother could not control her. ${ }^{32}$ The distinction between cases of delinquent children and those with mental disabilities was not always clear, since "feeble-mindedness" was a broadly applied, discriminatory diagnosis. ${ }^{33}$ In 1904, two brothers in Vancouver were placed in the PHI for "running at large" and being a "public danger" but were later confined to their home. In 1906, when a Nanaimo "imbecile" boy was removed from the PHI by his family, hospital superintendent Dr. Doherty predicted he "might become a criminal." ${ }^{34}$ The main public pressure to expand the detection of mentally defective children who also exhibited delinquency came from the Vancouver and Victoria "subnormal class" teachers. In 1917, Vancouver's subnormal class teacher, Josephine Dauphinee, spoke to the Vancouver Local Council of Women proclaiming "now is the time" to "remove from our midst these unfortunates, who through no fault of their own form the largest proportion of our poverty-stricken, criminal and socially degenerate class." 35 In 1917, Victoria's subnormal class teacher, Bertha Winn, also spoke publicly, telling a women's audience that "all mentally defective persons are antisocial" and the "only one way to deal with this stupendous evil" is by "segregating all cases of mental defectiveness from the normal population." ${ }^{36}$ Five boys and two girls "of this type" had been admitted to the PHI in 1903, where previously few had been accepted. At the time, the PHI's medical director, Dr. Manchester, believed that "a different kind of institution" as a training school was needed for these children. ${ }^{37}$ Specialized institutions for mentally disabled children in Canada emerged in the twentieth century, while in the United States, training schools or farm colonies for "subnormal" children were first established after the Civil War in New England and gradually spread to most states by the early 1900s. ${ }^{38}$ The province had created New Westminster's PHI in 1897 as an adult institution to replace the aging lunatic asylum. ${ }^{39}$

The Royal Commission on Mental Hygiene was established in 1925 and concluded its work in 1928, precipitating the passage of the Sexual Sterilization Act in $1933 .{ }^{40}$ Angus McLaren maintains the passage of a sterilization bill in British Columbia only came about with "the support of a large number of professionals" that were convinced such radical measures were necessary. ${ }^{41}$ Innovative mental hygiene initiatives such as child guidance clinics were first called for at the Victoria hearings 
of the royal commission. Olive Snyder of the Victoria Social Service League and Mrs. Charles Schofield of the Victoria Local Council of Women proposed preventive child clinics so doctors and nurses could "get to the root of the insanity problem by dealing with children suffering with insipient insanity." They urged the "establishment of a clinic for the treatment of children threatened with mental disease" and were supported by Dr. Clarence M. Hincks of the CNCMH and Dr. W.A. Dobson, a Vancouver physician. ${ }^{42}$

Mental hygiene increasingly influenced the local medical establishment. This can be seen in a November 20,1929, clinical section meeting held at the PHI by Essondale's medical director, Dr. A. L. Crease, with eighty-five doctors attending, many bused in from Vancouver. Various sessions were held: Dr. Crease spoke about traumatic psychosis, Dr. Ultan P. Byrne on manic depressive psychosis, and Dr. Louis E. Sauriol on imbecility and feeble-mindedness. ${ }^{43}$ However, the PHI's medical staff was frustrated because they had "to accept all mental types, from idiocy to acute insanity to senile dementia." "It was not until 1931 that two hundred "feeble-minded" children were moved from Essondale's "Home for the Feeble Minded" to the PHI under its new medical director, Dr. Louis Sauriol, who served as superintendent from 1931 to 1955 . This patient transfer was undertaken in order to begin to remake the PHI as a training school for mentally handicapped children. ${ }^{45}$ The supposed purpose of a child guidance clinic was to coordinate all the educational, custodial, court, and social service organizations dealing with these problem children under the psychiatric direction of doctors, psychologists, and social workers in order to facilitate treatment or institutional confinement.

\section{Opening British Columbia’s First Child Guidance Clinic, 1932-1939}

In July 1932, Dr. Arthur Lionel Crease, the medical superintendent of Essondale Mental Hospital, opened the provincial Child Guidance Clinic of British Columbia. The clinic was located at 763 Hornby Street in downtown Vancouver in "an old house that had been remodeled for the purpose." 46

Essondale was founded in 1904 as a rural farm colony of the PHI but was expanded in 1913 with the opening of the West Lawn hospital pavilion, followed by Centre Lawn, East Lawn, the Home for the Feebleminded, and the relocated Boys' Industrial School. By the 1930s, it was the province's main mental hospital. ${ }^{47}$ Dr. Crease had come to British Columbia in 1914 to work at the PHI after graduating in medicine from McGill University in 1910 and doing several years of postgraduate studies in Rhode Island. He became superintendent of mental health services at Essondale in 1926, and by 1934 , he was made provincial director of mental hygiene and psychiatry. Crease believed doctors should diagnose patients but that therapeutic care could be provided by specially trained nurses and social workers. Aside from "daily duties" with patients, Dr. Crease "carried on an informal teaching programme of the principles of mental hygiene" with the clinic staff of nurses, social workers, psychologists, and attending physicians. ${ }^{48} \mathrm{He}$ established a school for training psychiatric nurses and a provincial psychiatric social service department at Essondale. ${ }^{49}$ 


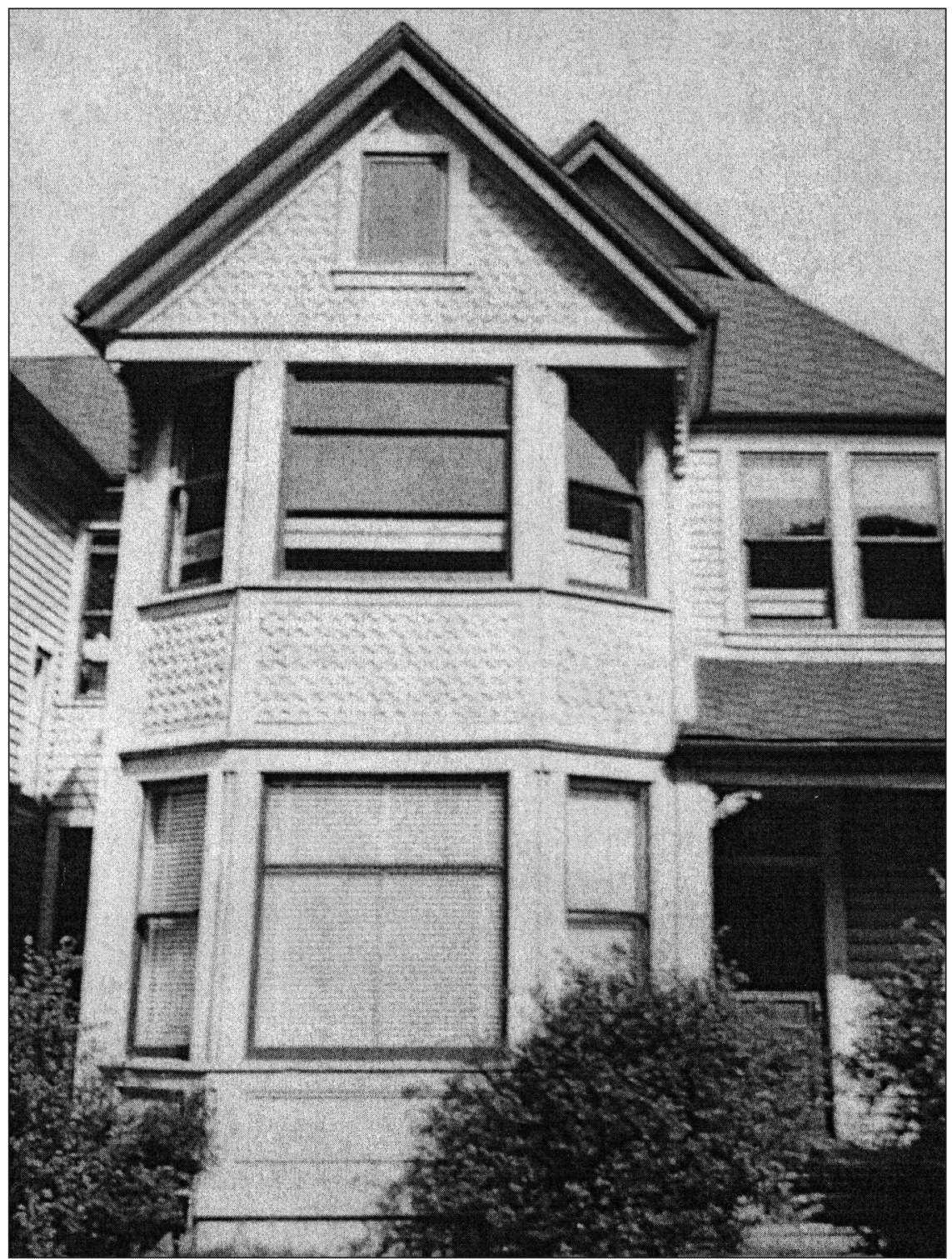

Figure 1. The first provincial Child Guidance Clinic located at 763 Hornby Street, Vancouver. Riverview Historical Society, item no. 906.

Although Crease's actual role in the provincial Child Guidance Clinic is unclear in its annual reports since he is rarely mentioned, it can be assumed he oversaw clinic operations.

The clinic conformed to the psychiatric wisdom of the time it was established. It should not be located in a hospital but rather in a residence "on a quiet street," to 
make children and families feel comfortable. Furthermore, the clinic should maintain a "close connection to the state hospital" or mental institution, and the psychiatrist's work should be "largely diagnostic" while treatment/case work would be conducted by psychologists and social workers. ${ }^{50}$ The provincial Child Guidance Clinic would operate only one day a week "owing to limited facilities" and would focus on "children requiring preventive treatment." Daily operation of the clinic was managed by Josephine Kilburn, a registered nurse with infant nursing experience who had also trained as a social worker. Kilburn had been brought to Essondale under a CNCMH grant in 1932 to promote psychiatric social work. ${ }^{51}$ In 1933 , she became part of Essondale's new social service department and by 1939 was supervisor of psychiatric social workers. In 1928, Kilburn was already establishing her expertise in the area of child mental health when she addressed a Toronto conference about "Parental Attitude and the Child." 52 She was a nurse in Toronto's Department of Health who specialized in the psychiatric problems of children. An expert on the "home adjustment" of the "problem child," she was frequently called in to deal with the children of parents "who had few educational advantages." It was always a challenge, Kilburn declared, to deal with these children who she considered to be "less fit" due to their "shortcomings in their intellectual" ability which led to "undesirable patterns" of behaviour. ${ }^{53}$ Kilburn ran the provincial Child Guidance Clinic using social workers drawn from Essondale's social service department and students from the social service diploma program at the University of British Columbia (UBC). Psychiatrists from Essondale acted as diagnostic clinicians; the clinic had no full-time psychologist until 1937..$^{54}$ The clinic's staff would "treat the child as an entity rather than deal with fractional parts" of the child's mental condition. ${ }^{55}$ The clinic "attempted to keep children from becoming psychotic" by trying to "redirect the already existing formation of poor and undesirable habits." 56 The focus of North American child guidance clinics had been set by 1927; they "restricted their concern to the ordinary problems" of normal children. Those "children with severe mental or physical problems were beyond the scope and mission of child guidance clinics" and would most likely be institutionalized. ${ }^{57}$

There was extensive use of intelligence testing. The medical staff conducted diagnostic examinations and categorized children's mental condition, and their "function soon was defined around diagnosis and consultation alone." Treatment protocols were recommended and "the social worker in most instances could take over individual treatment" comprising individual behaviour adjustment or habit correction. An analysis of 141 cases in the late 1940s indicated that "the burden of treatment was carried almost entirely by social workers" while the number of cases directly treated by psychiatrists was negligible. ${ }^{58}$ The prevailing psychiatric diagnostic manual was the Statistical Manual for the Use of Institutions for the Insane, also called the Statistical Manual, which had an overwhelming somatic (biological) bias; ten editions of this manual were published between 1926 and 1942. Its use in diagnosing children only became relevant in the tenth and final 1942 edition. ${ }^{59}$ The first textbook in the field of child psychiatry was published in 1935 by Leo Kanner of Johns Hopkins Medical School; he later went on to define autism in children. ${ }^{60}$ 
In its first year of operation, 129 cases were dealt with from July 1932 to March 1933; the diagnoses varied from an array of character disorders (autoeroticism, depression, tantrums, negative personality changes). The bulk of the cases came from the Vancouver Children's Aid Society, Catholic charities, and the Mother's Pension Department. All cases were assessed for intellectual ability using the Stanford-Binet Intelligence Scales (1916 edition; later 1937 revision). Those with below-average IQs (dull 80-90, borderline 70-80, moron 50-70, imbecile 25-50, idiot 0-25) accounted for 58 per cent, while those with average to bright IQs (average 90-110, superior 110-120, very superior $>120$ ) comprised 32.6 per cent; 9.3 per cent of the cases were not assessed. ${ }^{61}$ Many of these children exhibited "some degree of mental handicap" and were institutionalized; as a result of the clinic's actions, "the population of PHI rose to 412." 62 Kilburn stressed in her first clinic report "the whole idea of the clinic is that of prevention," but institutional confinement was aggressively utilized. A program of individual habit correction to rectify parental incompetence was often attempted and twenty-five home visits were made by clinic staff accompanied by various social service agencies. Kilburn used social workers in training from UBC as she dedicated "the clinic for student-work" as well as social service practicum students from McGill and Smith College, Massachusetts. ${ }^{63}$ The extensive use of social workers at the clinic raises the question of how these early British Columbia social workers were trained and how they were encouraged to view the children with whom they were dealing.

\section{Training the Social Service Workers of the Child Guidance Clinic}

Social workers were vital to the clinic's operations in the early years, which agrees with Jones's research on the Judge Baker Guidance Center in Boston. Using the names of the early social workers involved in the clinic's work, the 1932 Vancouver City Directory shows Barbra M. Robertson, Winifred M. Wiggins, and Isabel Rutter to be UBC students. Robertson resigned from the clinic in 1938 and Wiggins in 1939. They all began their training in 1930-31, the first session at which a social service diploma was offered at UBC's School of Social Work. Thirty units of course work were needed for the diploma, including requisite courses in biology, economics, sociology, psychology, social psychology, and ten social service courses. The courses were taught by Laura Holland (head of the Vancouver's Children's Aid Society), Mary McPhendren (head of the Family Welfare Bureau), Coral Wesley Topping (UBC sociologist), Edna Pearce (American-trained social worker for field work), Dr. Hill (Vancouver Health Department), and Ruby Kerr (Vancouver school psychologist). Kerr's association with eugenics as well as early special education in Vancouver's schools is well documented. ${ }^{64}$

The course work instilled a hereditarian mindset. In biology, students read William Castle's Genetics and Eugenics (1924) about the eugenic potential of human beings. ${ }^{65}$ In social psychology the "phases of mental life" were dealt with in Wilfred Trotter's Instincts of the Herd in Peace and War (1919). ${ }^{66}$ In 1932-33, a child psychology course was offered using the textbooks of Charles Spearman, Frank Freeman, 
and Lewis Terman. ${ }^{67}$ The course material was heavily biased towards the concept that inherited intelligence governed successful social adjustment. Environmental theories of child development appeared to be absent. Similarly, Eric Damer has found that, during summer sessions held by UBC's Faculty of Education in the 1920s, hereditarian theories of intelligence dominated teacher training. ${ }^{68}$ The hereditarian sentiments among UBC-trained social workers can be seen in Richard James Clark's 1947 plea that the province's Sexual Sterilization Act be strictly enforced. ${ }^{69}$ The social work students were largely female; only three men were enrolled in the program during 1931-33 out of a total of thirty-six students. ${ }^{70}$ Social workers were led to believe that many children's problems could be traced to their parent's low mentality and failure to provide proper structure at home. Employment in the new social welfare field was made possible by the provincial expansion of welfare services in 1933, and the Child Guidance Clinic was an important part of this. ${ }^{71}$

\section{The Child Guidance Clinic in the 1930s}

During the 1930s, a hereditarian approach dominated the provincial Child Guidance Clinic. It was not the rigid eugenic agenda of detection, institutional confinement, and then sterilization that was practiced in Alberta, but rather an over-reliance on intelligence testing and the limitations the low mental ability of a child placed on the effectiveness of therapeutic interventions. Although Kilburn continually made statements like "childhood is our most hopeful field," she seemed preoccupied throughout the 1930s with the low mental abilities of the children. In 1933-34, the first full year of clinic operations, 225 cases were seen. Of these, 147 were judged below average and 78 average or above according to the Stanford-Binet scales. About 205 "treatments" were carried out along with 63 home visits. Schools asked for the clinic's assistance when "the behaviour of the child has passed the realm of school discipline." 72

In the fall of 1934, Winifred Wiggins formally joined the clinic. New staff meant expansion; a clinic opened in Victoria at the Superior Street Annex and the Vancouver clinic scheduled one day a month for cases that "come from rural communities." Kilburn was frustrated by the number of children of low mentality and hoped "that the problem cases of normal intelligence will gradually increase." In 1934-35, the Victoria clinic had only 13 cases of average mentality and 20 cases of below-average intelligence. The Vancouver clinic had only 53 children with average ability and 162 below average. Kilburn stressed that "an evaluation of the intellectual equipment of the child" was necessary in "determining the material with which we are dealing." She believed "the determination of the intellectual equipment is imperative" when dealing with children and their parents. The clinic also examined children at the industrial schools, concluding "a considerable group of juvenile offenders" exhibited "feeble-mindedness." Kilburn was also lecturing to both social worker practicum students and visiting public health nursing students from UBC. ${ }^{73}$

In 1935-36, Barbra Robertson, a new social worker, joined the clinic staff and field offices were opened in Nanaimo, Courtenay, and Chilliwack, where the child guidance team held day clinics. By the 1940s these travelling clinics would be held 
in Penticton, Vernon, Nelson, Prince Rupert, Prince George, Cranbrook, and Kamloops. ${ }^{74}$ During 1936-37, the number of cases of intellectual "backwardness" declined, with such factors as shyness, irrational fears, and anti-social behaviour emerging as causal factors. However, of the over 400 Stanford-Binet tests administered, 155 children were of average intelligence and 247 below average. ${ }^{75}$ In 1937-38, the clinic staff was increased again with the addition of the first full-time psychologist, C. B. Watson, along with another social worker, Isabel Rutter. Maude Fleming, a graduate of the University of Toronto in social work, replaced Robertson. The new staffing levels and an increase in operating hours over several days a week would allow social workers to "talk over the plan of treatment suggested by the Psychiatrist" with parents. An increase in clinical "treatment" was supposed to occur, but there is little to no evidence of this change in direction. Of the 629 Stanford-Binet tests administered that year, the majority of children were still in the below-average intelligence range. Many cases of disturbed children coming to the clinic were blamed on "the unemployment of the father" in the lingering economic depression. Physically disabled children were sent to Vancouver General Hospital for "remedial physical treatment." More tutoring for reading and speech was being done by volunteer teachers, nurses, and even parents. ${ }^{76}$ By $1938-39$, the clinic was operating on a full-time basis. To Kilburn, therapy could encourage "right living," but the less-than-desirable home life of a child could not be altered. The clinic focus remained on the individual child: "his scholastic progress and deportment in school, his heredity, his emotional nature, his interests, ambitions, and dislikes." Too much clinic effort was being devoted to testing. The 630 Stanford-Binet tests consumed 356 hours of administrative time, while only 71 hours were given to direct therapy with 31 family meetings. Kilburn was forced to admit "the amount of work attempted is not always a criterion of its value or quality." 77

The value of the clinic's early work is suspect; others have seen this differently. In a master's thesis in nursing, Melissa Suzuki examined Kilburn's role in the Child Guidance Clinic. Although Suzuki admired her work with children and families, even she had to admit that Kilburn, as well as the clinic, "shows a moderate connection to eugenic practices." Suzuki believes that, "although Kilburn was for the most part humanitarian in her thoughts on mental illness, she did make statements that indicated class and race discrimination as well as a preference for working with children of average intelligence." Suzuki highlights statistics cited in Kilburn's 1935 report about mixed race children being at greater risk for mental health concerns. ${ }^{78}$ Evidence of this can be seen in table 3 of Kilburn's clinic report entitled "Problems as Seen by Clinic," where she lists some usual diagnoses as low mentality (41), physical disability (17), low mentality and physical disability (14), and mental illness (10). There were some strange findings, such as fantasy life (1), considered for deportation (1), wrong environment (20), standardization (37), and no moral sense (11). However, it is the diagnosis of racial differences (3) that tends to suggest Kilburn was linking race mixing to mental health problems in children. In subsequent years, the term "racial differences" never again appeared on any of the clinic's yearly diagnostic tables of children's problems. ${ }^{79}$ 
Table 1

Problems as seen by the clinic.

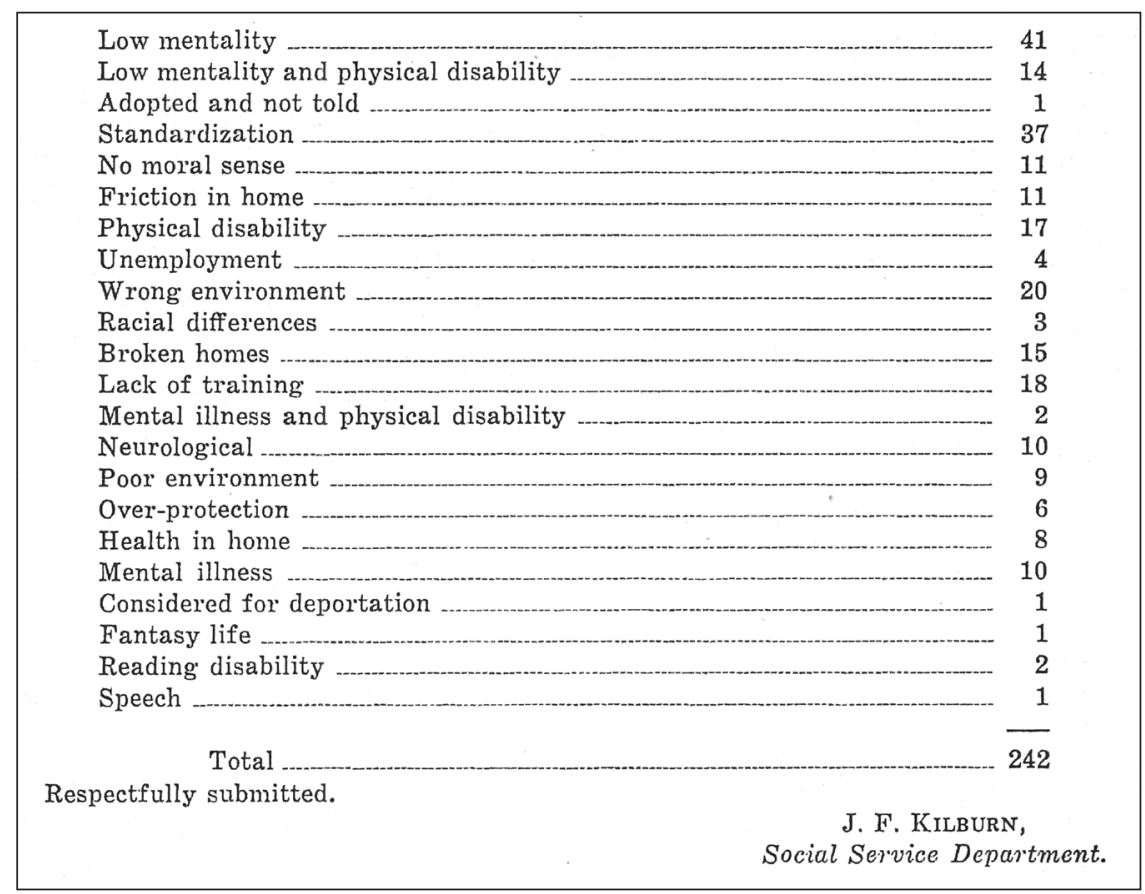

Source: Mental Hospitals Report, 1934-35, X19.

Hereditarian concerns were common among health professionals trained in the eugenics era. ${ }^{80} \mathrm{McLaren}$ cites the use of early provincial Child Guidance Clinic reports on families by the Provincial Eugenics Board. The clinic reports used "the pat phrase, the 'family history is not good', as sufficient evidence of hereditary taint." The link between the provincial Child Guidance Clinic and the Provincial Eugenics Board is not documented in yearly clinic reports and the low rates of sterilization in British Columbia casts doubt on the clinic's overall influence. ${ }^{81}$ The clinic's hereditarian biases placed severe limitations on its understanding of the children they were seeing.

\section{The War Years and the Clinic's Post-war Reorganization, 1939-1949}

In 1939, the board of the Alexandra Children's Home in Vancouver opened a treatment centre called Alexandra's Children's Cottage for cases of severe behaviour problems that the child guidance clinic could not accommodate. A social worker, Elizabeth Grubb, was given charge of twenty-one children but resigned due to job stress by 1941 and the venture collapsed in failure. ${ }^{82}$ In 1939-40, as the Second World War began, social worker Winifred Wiggins left the clinic, and Linda Smith took her place. 
A large-scale reorganization of clinic services was finally undertaken in earnest when local district agencies with their own field workers were created. A bi-monthly clinic was offered for the "school children of New Westminster." Kilburn noted a distinct difference in the children the clinic was beginning to see. Behaviour problems in children "falling in the group of average intelligence" were increasingly found. By 1940-41, long-term family therapy began to consume many clinic hours. Kilburn had public health nurses from UBC come to the clinic for "study and observation" and apparently gave a series of ten lectures at UBC's School of Nursing. ${ }^{83}$ In 194142 , middle-class parents began bringing their children to the clinic. This should have pleased Kilburn, but apparently it did not:

The business executive, the family physician, the lawyer, judge, or parent run up against problems which baffle them and they subsequently call us for expert help. These are not easy cases to adjust. They have already been dealt with by intelligent people and still have not improved. ${ }^{84}$

These middle-class, professional families were "often argumentative" and even challenged the psychiatrist. ${ }^{85}$ Kilburn's hereditarian belief that the low mentality of children from the labouring classes of society was the prime factor in many clinic cases was being challenged. The 1942-43 caseload statistics illustrated the dilemma: 172 children had average intelligence scores, while 198 had below-average intelligence. There were only 26 more cases of below-average intelligence when compared to those with average intelligence. The clinic lost staff to the armed forces, and replacements had "wider experience in other fields." ${ }^{86}$ In 1942, the clinic was moved to "a large private home near the City Hall" of Vancouver from its original location. Staff shortages remained critical and the budget strained ${ }^{87}$ In her 1944-45 report, Kilburn blamed this sudden increase of problem children of normal intelligence on the war. The clinic had to "obtain emergency help from Dr. Crease" on many cases. It was the "troubled times" and the fact that many fathers were absent in military service that created "unnatural home conditions." Kilburn "anxiously looked forward" to the end of the war. ${ }^{88}$ Her views appeared to be moderating by 1944 when she wrote, "you cannot treat an individual only, but the environment in which he lives must also receive attention." ${ }^{9}$

At the end of the war, profound changes came to the provincial Child Guidance Clinic. A new psychologist, Marjorie Munro, is mentioned and the previous psychologist, C. B. Watson, disappears from the reports after 1939. Kilburn wrote her own report on the clinic within the Essondale social service report in which she admitted the clinic had "little to offer" in the way of remedial or preventive support for "emotionally maladjusted" children..$^{90}$ The arrival of a new clinic director, Dr. Ultan Patrick Byrne, caused extreme distress for Kilburn. Born in New Westminster in 1901 to a pioneer Burnaby family, Dr. Byrne was a medical doctor with psychiatric training. He attended the University of Toronto and began working at Essondale Mental Hospital in 1926 as a laboratory pathologist. During his time as a pathologist, he lived at Essondale in a doctor's residence. Byrne was also a doctor of public 
health (DPH) and a fellow of the American Public Health Association. ${ }^{91}$ In Byrne's first half-year report of 1945-46, he recommended four psychiatric teams with a child psychiatry specialist, two psychologists, four psychiatric social workers, and clerical support. He proposed one team in Victoria, two teams in Vancouver, and a travelling team for the rest of the province. ${ }^{92}$ His mandate was to update the medical practices of the clinic in the name of "public mental health," and he immediately began "incorporating psychiatry into community activities." In 1946-47, his first full year as clinic director, Byrne held 773 case conferences and 197 consulting conferences. Twenty-three public health nursing students came to the clinic to observe these. He expressed regrets that the psychiatric teams could not be created due to a scarcity of trained personnel..$^{33}$

According to Suzuki "there was tangible tension between Byrne and Kilburn." Kilburn continued to write separate year-end reports; her reports sought to preserve the teaching role of the clinic for social workers and acknowledged that social workers now received "psychiatric interpretation" on their cases. ${ }^{94}$ This suggests that clinic social workers were in fact not operating under strict medical direction in the past, and it appears Kilburn now resented this oversight from Byrne's medical team. Dr. Byrne had served in the Canadian army from 1943 to 1946 in the Pacific Command as a hygiene officer, obtaining the rank of major. ${ }^{95}$ The war profoundly affected psychiatry in general and launched significant changes in the way environmental stress was thought to contribute to mental maladjustment. Byrne attended the University of Toronto after the war to study industrial mental hygiene at the School of Public Health where he qualified as a DPH. ${ }^{96}$ Dr. Byrne moved back to New Westminster and lived there until his death in $1959 .{ }^{97}$ Byrne can generally be described as a practitioner of orthopsychiatry because he followed the prevailing medical understanding of the time that mental illness in children could be prevented with the appropriate diagnosis. Individual psychodynamic adjustment therapy was given to a child only after an array of medical and psychiatric diagnostic criteria were evaluated using the tenth edition of the Statistical Manual (1947), which included a special section on the behaviour disorders of children. ${ }^{98}$ Commonly used treatments for mentally ill adults could not be used on children. These included thermal-hydro (first used in 1906 at the PHI), insulin shock (begun in 1937 at Essondale), electroconvulsive therapy (begun in 1942 at Essondale), and in extreme cases, surgical procedures such as lobotomy (selectively done beginning in 1945 at Essondale). ${ }^{99}$ The first psychotropic drug therapies would only begin to be used in the 1950s. In children, psychodynamic adjustment therapy was used in addition to physical and learning interventions. ${ }^{100}$ The first drug treatment for behaviour disorders in children had been conducted in 1937 with benzedrine sulfate but was largely ignored until the 1960s. ${ }^{101}$ Dr. Byrne became a psychiatric consultant at the Vancouver Children's Hospital and worked as a lecturer for the British Columbia provincial police specializing in the crimes of youthful offenders. ${ }^{102}$

In Dr. Byrne's second year as clinic director, his new clinical methods began to yield results. In 1947-48, using new statistical and diagnostic techniques, he found a group of "children whose intelligence is average or higher, but who are educationally 
retarded for a variety of reasons." There was more "careful study and observation" of each child to ascertain the "suitability" of various types of individual medical investigations. ${ }^{103}$ Parents were being sent to the clinic for family therapy along with their children by the mental hygiene division of the Vancouver school system. ${ }^{104}$ In 1948-49, new diagnostic tests were introduced to the clinic beyond standard intelligence tests. Various personality tests, vocational aptitude tests, reading tests, visual-motor tests, specialized tests for the deaf, and other deficit-specific assessments were adopted. The new diagnostic criteria for cognitive disabilities resulted in only sixteen cases being linked to borderline intelligence, while other causes were identified as writing, reading, and arithmetic problems. Mental deficiencies were assigned causal factors such as familial, mongolism, developmental cranial anomalies, congenital spastics, postinfection, post-traumatic, endocrine disorders, epilepsy, organic nervous disorders, and mental retardation. Broad clusters of disorders were used for case diagnostics as "Primary Behaviour Disorders" (Habit, Personality, Neurotic, Conduct), "Psychotic/ Pre-Psychotic Disorders," "Psychoneurosis/Neurosis," and "Convulsive Disorders." The largest group of case disorders fell in the "Conduct" category, which included stealing, running away, or disobedience. "Habit" disorders comprised bedwetting/ tantrums in younger children and sexual disorders centring on excessive masturbation in older boys. "Personality" disorders were exhibited through depression, aggression, and feelings of inadequacy. "Neurotic" disorders were expressed through anxiety, nervousness, and hyperactivity. "Psychotic" and "Psychoneurotic" cases were rare while "Convulsive" disorders were commonly seen in epileptics. "Mental Deficiency Disorders" now made up only an isolated number of cases with specific medical causes such as mongoloidism; they were no longer called "feeble-minded." Dr. Byrne wrote in his 1948-49 report that the case data he collected in "these tables are based on the complete examination or re-examination of each case." In this period, 608 children were referred to the clinic by social agencies, while only 43 were referred by public health nurses, since most cases continued to come from custodial agencies such as the industrial schools (60), juvenile courts (45), Borstal school (119), and just 5 from public schools. ${ }^{105}$ The medical reforms Dr. Byrne made to the diagnostic procedures of the clinic were based upon the International Classification of Diseases (ICD), Revision 6 (1948) which would later be incorporated into the DSM-I. ${ }^{106}$ Dr. Byrne's clinic reforms were medically progressive as well as necessary after years of questionable clinical practices.

The direction of the clinic before Dr. Byrne's arrival can be gauged from several draft documents of speeches/talks from the 1940s found in the files of the provincial Child Guidance Clinic at the Riverview Hospital library before its closure. ${ }^{107}$ A 1946 speech on "The Normal Child" bluntly states that "heredity sets the limits of assets and liabilities" in youngsters. ${ }^{108}$ A 1942 speech on "Heterosexual Interests and Activities" states that, while "erotic stirrings" are normal in children, the child from "an uncultured family background . . . exposed to verbal obscenities" will lack "restraint and tactfulness." ${ }^{109}$ In 1942, the Juvenile Delinquents Act was amended to included "sexual immorality." 11047 talk on "The Family and the Home" was based on the work of California eugenicist Dr. Paul Popenoe. ${ }^{111}$ A 1948 speech on 
Table 2

Problems and disorders seen at the provincial Child Guidance Clinic from 1948 to 1949.

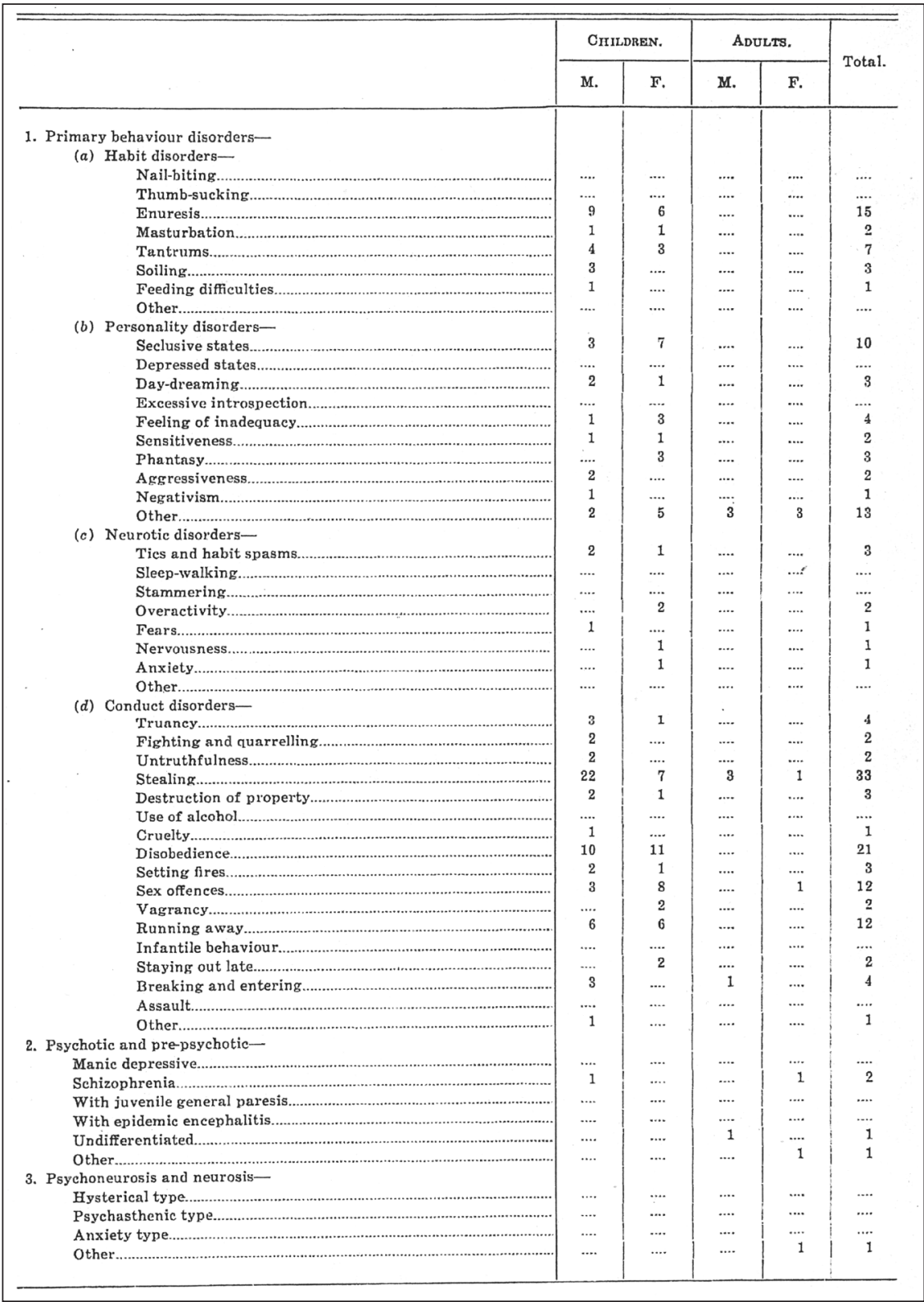




\begin{tabular}{|c|c|c|c|c|c|}
\hline & \multicolumn{2}{|c|}{ ChILDREN. } & \multicolumn{2}{|c|}{ Adults. } & \multirow{2}{*}{ Total. } \\
\hline & M. & F. & M. & F. & \\
\hline \multicolumn{6}{|l|}{$\begin{array}{l}\text { 4. Convulsive disorders- } \\
\text { Epilepsy }\end{array}$} \\
\hline Epilepsy & 4 & 1 & & $\ldots$. & 5 \\
\hline 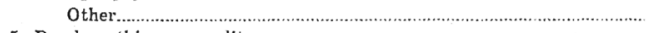 & $\ldots$ & $\ldots$ & $\ldots$ & $\ldots$. & .... \\
\hline 5. Psychopathic pe:sonality & 2 & 3 & 2 & 2 & 9 \\
\hline \multicolumn{6}{|l|}{ 6. Educational disability- } \\
\hline (a) Associated with dull normal or border-line intelligence. & 12 & 4 & $\cdots$ & $\ldots$ & 16 \\
\hline \multicolumn{6}{|l|}{ (b) Special mental disability- } \\
\hline 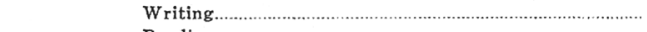 & $\ldots$ & $\cdots$ & $\cdots$ & $\ldots$ & $\ldots$ \\
\hline Reading & 6 & 1 & $\ldots$ & .... & 7 \\
\hline 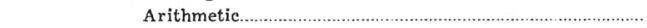 & .... & .... & $\ldots$. & $\ldots$ & .... \\
\hline 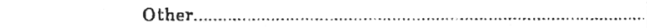 & .... & 1 & $\ldots$. & $\ldots$. & 1 \\
\hline \multicolumn{6}{|l|}{$\begin{array}{l}\text { 7. Mental deficiencies- } \\
\text { (a) Famelial..................... }\end{array}$} \\
\hline $\begin{array}{l}\text { (a) Famelial......... } \\
\text { (b) Mongolism..... }\end{array}$ & $\cdots$ & 3 & $\ldots$. & $\cdots$. & 6 \\
\hline 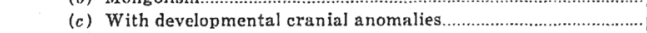 & 1 & $\ldots$. & $\ldots$. & $\ldots$. & 1 \\
\hline (d) With congenital spastics & 2 & 2 & $\ldots$. & $\ldots$ & 4 \\
\hline 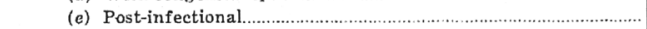 & $\ldots$ & 1 & $\ldots$ & $\ldots$ & 1 \\
\hline (f) Post-traumatic & 3 & 1 & $\ldots$. & $\ldots .$. & 4 \\
\hline (g) With epilepsy & 2 & 1 & $\ldots$ & 1 & 4 \\
\hline 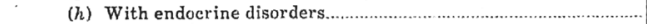 & .... & .... & $\ldots$. & & \\
\hline (i) With other organic nervous disorders & 1 & $\ldots$ & $\ldots$. & $\ldots$. & 1 \\
\hline 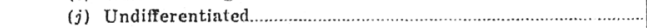 & 24 & 14 & 1 & 2 & 41 \\
\hline (k) Other & $\ldots .$. & $\ldots$ & $\ldots$ & $\ldots$ & $\ldots$. \\
\hline \multirow{2}{*}{\multicolumn{6}{|c|}{$\begin{array}{l}\text { 8. Mental retardation } \\
\text { 9. No ascertained mental deviation - }\end{array}$}} \\
\hline & & & & & \\
\hline (a) Problem of physical health and development..... & .... & 1 & $\ldots$. & 1 & 2 \\
\hline (b) Spastics & 4 & 5 & $\ldots$. & .... & 9 \\
\hline (c) Speech problems & 6 & 5 & .... & $\ldots$. & 11 \\
\hline 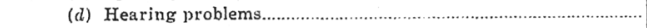 & 4 & $\ldots$ & $\ldots$. & $\ldots$ & 4 \\
\hline (c) School problems & 1 & 3 & $\ldots$. & $\ldots$ & 4 \\
\hline \multicolumn{6}{|l|}{ (f) Social problems....... } \\
\hline (1) Placement & 13 & 16 & $\mathrm{I}$ & $\ldots$ & 30 \\
\hline (2) Adoption & 91 & 74 & $\ldots$. & $\ldots$. & 165 \\
\hline (3) Unmarried mother. & $\ldots$. & 8 & $\ldots$. & 54 & 62 \\
\hline (4) Married mother & .... & $\ldots$. & $\ldots$. & 2 & 2 \\
\hline (5) Other & .... & $\ldots$. & $\ldots$ & $\ldots$. & .... \\
\hline$(g)$ Unascertained & $\ldots$ & 1 & $\ldots$. & $\ldots$ & 1 \\
\hline (h) Normal personality & 15 & 7 & .... & $\ldots$ & 22 \\
\hline 10. Vocational guidance & 3 & 4 & 1 & 5 & 13 \\
\hline 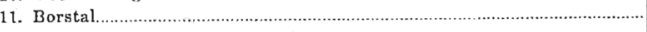 & 11 & $\cdots$ & 87 & $\cdots$ & 98 \\
\hline Totals..... & 303 & 231 & 103 & 75 & 712 \\
\hline
\end{tabular}

Source: Mental Hospitals Report, 1948-49, HH32-HH33.

"Pre-School Development" told parents at Bayview School in Vancouver that "psychometric ratings" alone could guide their child's development. ${ }^{112}$ A 1947 description of clinic operations made it clear that there was no way to help a child where "feeblemindedness is the central problem." 113 The clinic wanted children with easy fixes, such as Elizabeth, an eight-year-old bedwetter whose parents had caused her nervous condition. ${ }^{114}$ A master's thesis examined the cases of 257 children from 1945 to 1947 and found most cases of "low intelligence" came from "delinquency areas." Many of the fathers seen at the clinic were labourers; few were businessmen or professionals. Most of the mothers from labouring families suffered from "mental distrurbances" and the fathers "used alcohol to excess." The fathers of labouring families had little knowledge of their child's school progress. ${ }^{115}$ These documents show the clinic was socially biased against the families and children from the labouring class before Dr. Byrne's reforms. 


\section{The Child Guidance Clinic Under Dr. Ultan Patrick Byrne in the 1950s}

Dr. Byrne altered the diagnostic and treatment procedures of the provincial Child Guidance Clinic by changing its clinical practices into a modern medical diagnostic child development agency. In March 1949, the house next to the clinic at 455 West 13th Avenue was bought for the expanding caseload. The opening in 1950 of Woodlands School for the Mentally Retarded in the old PHI facility in New Westminster finally provided a dedicated hospital setting for mentally or physically handicapped children. A 1950 radio talk by Dr. Byrne about the provincial Child Guidance Clinic made it clear that mentally retarded or "exceptional" children would "require adequate facilities for proper education." New community facilities were beginning to open due to the efforts of the parents of these children who received direct help from the Child Guidance Clinic. ${ }^{116}$ In addressing this matter, Dr. Byrne declared in a 1950 speech on the "Retarded Child" that there needed to be a "greater emphasis . . . placed on cultivation of the child's . . . assets." ${ }^{117}$ More attention had to be placed on the treatment of children away from the clinic. It is best "to detect and treat children's difficulties ... in the community." 118 Dr. R. G. E. Richmond was appointed to handle all referrals from the industrial schools, courts, Borstal school, and all adults from the Oakalla Prison Farm. Dr. Byrne could now deal with the "noticeable increase in cases from . . private physicians." ${ }^{119}$ By 1950-51, referrals from the courts (148) and the industrial schools (108) no longer provided the bulk of clinic patients, since "referrals from medical and health agencies, schools and professional and private referrals" had dramatically increased. Cases from medical and health agencies (123), schools (22), physicians (61), and parents (69) were significantly higher, while social agencies (518) accounted for the remainder of the referrals. The increased number of diagnosed cerebral palsy cases were sent to Children's Hospital and twenty-four congenital spastics were sent to the School for Spastics Rehabilitation Centre in Vancouver. ${ }^{120}$ Dr. Richmond, a trained psychiatrist, was the first medical officer for the Oakalla Prison Farm. ${ }^{121}$

In 1951-52, the clinic saw fifty-five cases of mental retardation. Older children exhibited mostly "conduct disorders" such as stealing (136), alcohol use (15), breaking and entering (40), and sex offences (25). Younger children had mostly "habit disorders" such as bedwetting (31) and tantrums (18). Dr Byrne remarked that most of the cases had "average to better-than average intelligence." "Correction Teams" of social workers with a psychologist worked closely with agencies responsible for delinquents and they had a "busy year." 122 In 1952-53, the situation remained much the same, since "conduct disorders" in older children typified by stealing (87), breaking and entering (34), and sex offences (22) dominated. Younger children continued to exhibit disorders such as bedwetting (36) and tantrums (33). ${ }^{123}$ Ricketts, the social worker supervisor, was alarmed by the severely disturbed older children the clinic was seeing and saw "the need for a residential centre for these children" as home support or foster home placement was simply not adequate. ${ }^{124}$ Testing data continued to show that the number of children with average to above-average intelligence (577) was growing, while the number with below-average intelligence (352) continued to 


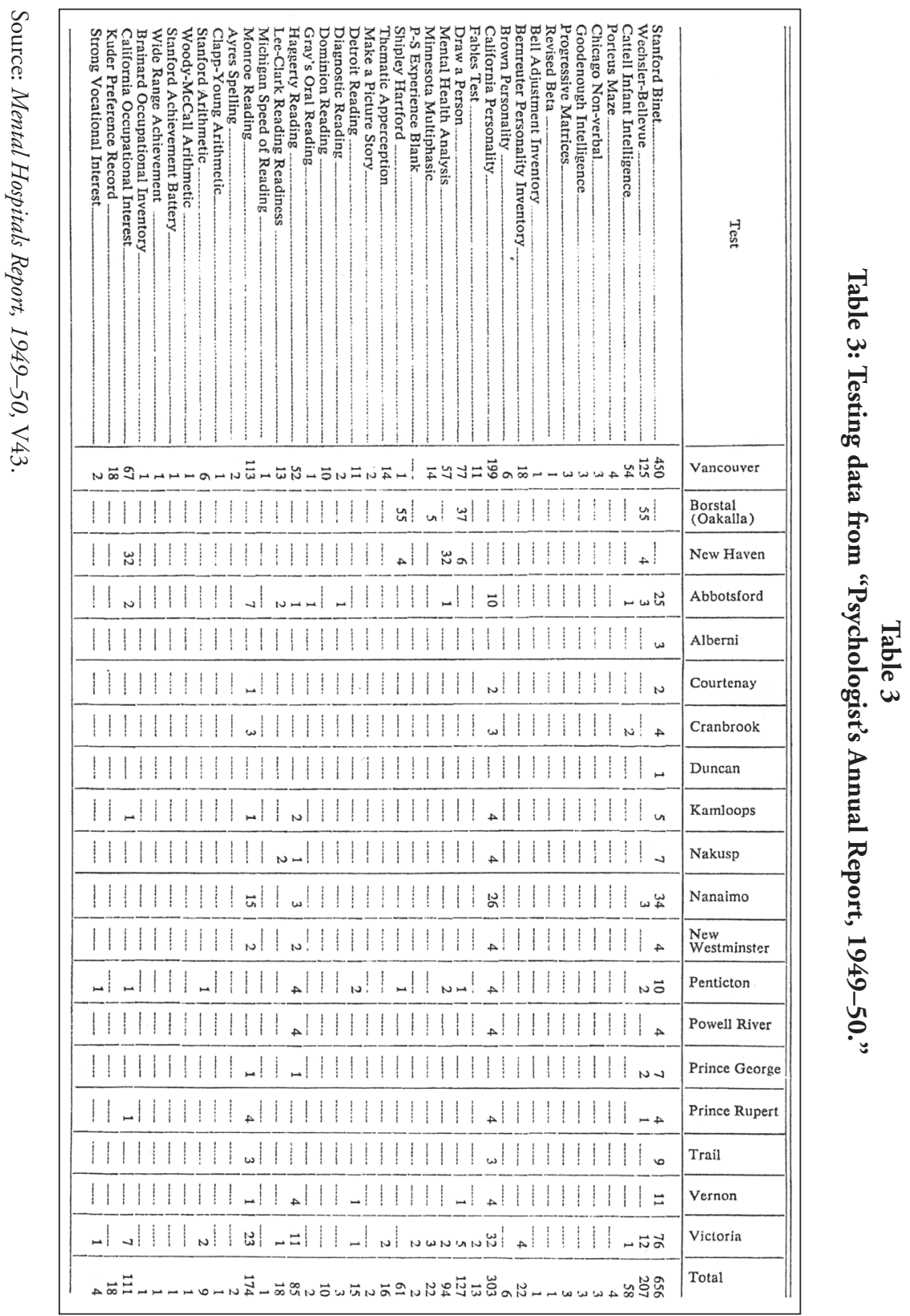


decline. Byrne believed the growing referrals of children from medical/health agencies, private physicians, parents, and relatives indicated "a growing awareness of the value of the Clinic's services," resulting in a change of clientele. ${ }^{125}$

By 1953-54, Dr. Byrne appealed for a residential treatment facility "for emotionally disturbed pre-adolescents." Ricketts, the social worker supervisor, was concerned about the caseloads the social workers were handling. An average of about forty-eight cases required direct service. In one month, each social worker was expected to see twenty-nine parents and twenty children. More case referrals were now coming from family physicians, health agencies, and schools (39.06 per cent) while social welfare agencies were sending fewer children (36.76 per cent). The industrial schools and juvenile courts still sent 269 cases to the clinic. Most of the cases centred upon "conduct disorders" in older children, such as stealing (75), but a rise in sex offences (41) was noted. Younger children were still largely referred for bedwetting (37) and tantrums (15) but now could be treated using play therapy. ${ }^{126}$ In 1955, a major source of case referrals relocated; the Boys' Industrial School moved from Essondale to Brannan Lake on Vancouver Island. ${ }^{127}$ In 1959, the Girls' Industrial School moved from Vancouver to Burnaby, becoming the Willingdon School for Girls. ${ }^{128}$

Despite this, the psychology department complained of a lack of trained staff and the temporary acting head of social work, Robert Macdonald, stated that "without additional space and staff, a waiting period will be necessary." More work fell to the "Brief Service Section" in the social service department. Dr. Byrne bluntly stated that "requests for service exceed our ability to meet them," and this situation "has not been lessened," despite internal reorganization. Case referrals continued to shift; medical/health agencies sent 318 cases to the clinic. Various public/private social agencies referred 393 cases, but parents, relatives, and family friends referred 129 cases. Schools sent 62 cases to the clinic. ${ }^{129}$

It was obvious that parents, probably on the advice of family doctors, now felt comfortable seeking the clinic's mental health support for their problem children. In 1954, plans were announced to hire new clinic staff and construct a new purposebuilt facility in suburban Burnaby on Willingdon Avenue. The new Child Guidance Clinic and Mental Health Centre would be a community-based facility housed in adjoining buildings. ${ }^{130}$ Dr. Byrne believed "some of our more pressing needs will be met by the opening" of this new facility. ${ }^{131}$ This seemingly represented a major investment in mental hygiene by the new Social Credit government. The facility would include "one-way mirrors, microphones and recording systems" that would "enable psychiatrists to watch a child's behavior from a hidden vantage point." It would also serve as headquarters for "a travelling unit." 132 Dr. Byrne was not optimistic: "we are still faced with the problem of getting and keeping well-trained, experienced, and competent personnel." Marjorie Munro, the senior psychologist, was also hesitant; she said that "the impending staff shortage" is "so serious that it may affect not only our standards, but the quality of the work done by the clinic." The returned social work supervisor, D. B. Ricketts, seemed more positive: "There is every reason to expect greater service to parents and children and better work satisfaction for staff in the new setting." However, he noted that eight social workers left 
and three vacancies remained at year-end. ${ }^{133}$ The clinic staff was not very optimistic about their situation.

On May 1, 1957, the new Child Guidance Clinic officially opened; Dr. Byrne and Dr. F. E. McNair, director of the Mental Health Centre, officiated. With a staff "of about forty," it was described as a "resource for children" who had an "inability to cope with social or scholastic expectations." ${ }^{134}$ Soon after this hopeful event, three psychologists and four social workers resigned. Dr. Byrne wrote the "loss of well-trained persons . . . is producing a vicious circle." There was a "decline in the attractiveness of the clinic as a training centre." The psychology department examined 1,036 cases in 1956-57; there was a "marked drop" in treatment services. The travelling clinics were doing mainly diagnostic interviews $(1,161)$ and relied on the Burnaby clinic for treatment interviews (103) for a total of 1,264 interviews. The waiting lists for treatment swelled to "about a year." The head psychologist, Marjorie Munro, bluntly declared it "had reached the point where it cannot continue much longer." 135 The "Brief Service Section" continued to treat children, which belied the fact that staff shortages probably made the procedure necessary. Research on the method was not complimentary. ${ }^{136}$ There was a great deal of general research interest in the operation of the Child Guidance Clinic from graduate students in social work at UBC almost until the moment the clinic was closed, demonstrating their continued support for child mental hygiene work. ${ }^{137}$

In 1957, the clinic marked twenty-five years of service, but the mood was not celebratory, since travelling clinics in Penticton, Kelowna, Cranbrook, and Creston were cancelled due to staff shortages. The Burnaby and Mainland travelling clinics could only see thirty-four new cases each month, down from eighty-one per month in the previous year. Federal mental health grants were being used to hire social workers, but three psychologists resigned, leaving only one qualified psychologist. A. Clemons was engaged as a speech therapist. Dr. Byrne sombrely reported that "there has been an appreciable decrease in the total number of cases given full examination, an overall loss of 12 per cent."138 In January 1958, the Child Guidance Clinic was abruptly closed by the provincial government and incorporated into the Provincial Mental Health Centre as the Children's Clinic Program. Dr. Byrne resigned and was replaced by Dr. F. E. McNair as the children's program director. In September 1958, McNair and Byrne published an article in a scholarly medical journal extolling the work of the now-disbanded Child Guidance Clinic. ${ }^{139}$ Dr. Byrne took a position at the private Hollywood Hospital in New Westminster, where he became involved with the hospital's LSD (lysergic acid diethylamide) drug trials. Ultimately he found the therapy to be of no clinical value. ${ }^{140}$ Dr. Byrne died suddenly in July 1959 at the young age of fifty-eight, after completing his work on LSD. ${ }^{141}$

\section{The Political Reasons Behind the Clinic's Closure}

The closure of the clinic was closely tied to the Social Credit government of British Columbia, first elected in 1952. After being elected, the new government promptly began an ambitious agenda to "improve the hospital insurance program" 
while building new hospitals, schools, highways, and hydroelectric power dams. ${ }^{142}$ However, the British Columbia Social Credit party had no ideological commitment to eugenics policies, as was the case with the Social Credit party in Alberta. In British Columbia, mental hygiene was a dispensable agenda for the Social Credit government by 1958 and one of the casualties was the provincial Child Guidance Clinic. In the early 1950s, new health care funds were initially devoted to child mental health. The first sign of retrenchment came in 1958 when social workers in the mental health field were cut back. ${ }^{143}$ This led to large-scale cutbacks at all mental health facilities, particularly Woodlands School. ${ }^{144}$ Debate in the legislature became heated when the opposition Cooperative Commonwealth Federation (CCF) accused the government of attacking various provincial mental health institutions. ${ }^{145}$ The press questioned why, in such a prosperous province as British Columbia, the Social Credit government was destroying social services for helpless children and mentally troubled adults. ${ }^{146}$

It became apparent the cutbacks were selectively affecting mental health, education, youth/adult correctional services, and social worker services in order to generate cost savings. ${ }^{147}$ The British Columbia Psychological Association stated a "deterioration in both the extent and quality of services" at many mental health facilities, especially the Child Guidance Clinic, was occurring. In a letter to Premier W. A. C. Bennett, the association claimed that any "former progress has ceased and staff are demoralized; and the mental health and correction services are regressing." 148 Provincial Secretary W. D. Black said the rising costs of caring for the "mentally ill" and "mental defectives" was becoming financially prohibitive. ${ }^{149}$ Public backlash and doctor protests did result in some retrenchment. ${ }^{150}$ CCF legislator Tony Gargrave called the cuts "a public disgrace." He declared that the government's rationale for the cuts based on debt reduction and preserving the province's credit rating was "even more disgraceful." ${ }^{151}$ The Canadian Medical Association wrote to Black denouncing the cutbacks. ${ }^{152}$ The Vancouver Sun wrote:

The Child Guidance Clinic and Mental Health Centre with both day and night hospital facilities available built at Grandview and Willingdon 13 months ago at a cost of $\$ 813,255$ is doing less than half the work it is equipped to do because of staff shortage[s]. The Child Guidance Clinic has a waiting list of up to two years. Many of these youngsters with behaviour problems break down completely or turn into delinquents before they can get the treatment they need, doctors claim. ${ }^{153}$

Doctors in British Columbia were still using the same mental hygiene arguments they had employed to get the Child Guidance Clinic established in the 1930s - the fear of the social consequences of not dealing with "problem children." However, the British Columbia Social Credit government was no longer interested in such alarmist mental hygiene agendas. 


\section{Conclusion}

This paper has thoroughly examined British Columbia's Child Guidance Clinic from its founding in 1932 until its abrupt closure in 1958 and has reached several conclusions about the clinic's unique history. In its early years, the Child Guidance Clinic served a preponderance of children with low intelligence, as determined through standardized intelligence testing. Clinic head Josephine Kilburn sent many to the PHI and longed for children of normal intelligence who were more suitable for behavioural adjustment treatment. Throughout the 1930s and 1940s, the clinic represented the hereditarian and class biases of a staff largely made up of social workers who had been trained at UBC's School of Social Work in the early 1930s. There is evidence they were not necessarily trained in the new environmental theories of child psychology; they continued to rely upon hereditarian beliefs about intelligence and the supposed biological limits of helping "problem children." Kilburn may have expressed her belief in the best interests of the child and the value of family therapy, but at the same time, she deplored mixed-race children, whom she regarded as untreatable because of their heredity. When finally faced with a large number of children of normal intelligence from middle-class backgrounds in the Second World War, Kilburn continued to complain, "these are not easy cases to adjust." 154 The uncredited text of speeches/talks given by the staff of the provincial Child Guidance Clinic in the 1940s found at the Riverview Hospital Library revealed class prejudices against erotic stirrings in "uncultured families;" they also made it clear that the "feeble-minded" were simply not wanted at the clinic. The master's thesis by Evelyn Marie Roberts examining clinic cases between 1945 and 1947 clearly showed a pattern of class prejudice against labouring families who supposedly had alcoholic fathers and mentally ill mothers. Richard James Clark wrote in 1947 that many cases of mentally defective children could be permanently dealt with by the judicious application of sterilization; he was simply reflecting the hereditarian bias of his profession. Aside from these overt prejudices, the early clinic was strained by continual staff shortages, limited hours of operation, and an inability of its social workers to deal with children from certain social backgrounds. As a medical agency meant to help "problem children" and their parents, the early period of the Child Guidance Clinic can be characterized as dysfunctional.

The clinic's medical practices were dramatically reformed by Dr. Ultan P. Byrne after he took charge in 1947. With Kilburn in the background, hereditarian social assumptions diminished as diagnostic procedures became based upon current medical standards and qualified medical personnel directed social workers about case treatment. Detailed case statistics were collected for analysis in order to improve diagnostic techniques. Dr. Byrne's reforms to clinical practices increased the number of cases of children being referred by the local medical community for mental health treatment. The 1950 opening of Woodlands School for "mentally retarded" children in the old PHI changed how the clinic dealt with cases of mentally or physically disabled children. The closure of the Boys' Industrial School at Essondale in 1955 and its move to the Brannan Lake facility near Nanaimo on Vancouver Island also 
decreased institutional case referrals, as did the 1959 opening of a new Willingdon facility in Burnaby to replace the aging Girls' Industrial School. This allowed the clinic to concentrate on treating more children from the community who were referred by the local medical community and schools for mental health treatment. As caseloads rose in the 1950s, staff shortages became problematic, and when a new Child Guidance and Mental Health Centre was proposed for Burnaby in 1954, Dr. Byrne was skeptical. No sooner had the facility opened in 1957, staff shortages and high caseloads doomed the effort, and the provincial Child Guidance Clinic was abruptly closed in 1958 following its twenty-fifth anniversary. Dr. Byrne left to work in a private sanitarium and died shortly thereafter. The meagre efforts made to provide mental health services for "problem children" by 1962 were described by thenChildren's Program director Dr. K. J. Davies: "The requests for service are enormous, and treatment only possible for a minority." 155

British Columbia's provincial Child Guidance Clinic was born out of a public commitment to mental hygiene in the early 1930s. However, it was burdened in its first decades of operation by an outmoded hereditarianism and the leadership of a nurse-social worker whose class and racial prejudices made the therapy offered to some children highly problematic. Medical reform under the leadership of a psychiatrist from 1947 into the 1950s did improve the clinical treatment of the children themselves but the burden of staff shortages and underfunding belied a lack of political commitment by British Columbia's Social Credit government to the mental hygiene treatment of children. To British Columbia's "socred" politicians, such efforts were a waste of funds, while Alberta's Social Credit remained stalwart adherents until they lost political power in the 1970s to the principles of mental hygiene for children in order to curb the threat of the "feeble-minded." Long-term political and public support made Alberta's child guidance clinics a highly effective public agency while British Columbia's clinic appeared rather ineffective over its twenty-five years of operating history.

\section{Notes}

I would like to thank the anonymous reviewers and editors of Historical Studies in Education/ Revue d'histoire de l'éducation for their guidance in revising this paper. I would also like to thank the late Corinne M. Douglas for her research assistance in its preparation.

1 Thorbjorn Lengborn, “Ellen Key (1849-1926)," Prospects: The Quarterly Review of Comparative Education 23, no. 3-4 (1993): 825-37.

2 Donald K. Pickens, Eugenics and the Progressives (Nashville: Vanderbilt University Press, 1968).

3 Theresa Richardson, The Century of the Child: The Mental Hygiene Movement and Children's Policy in the United States and Canada (Albany, NY: SUNY Press, 1989), 27, 89.

4 Richardson, The Century of the Child, 5.

5 August Weismann, The Germ-Plasm: A Theory of Heredity (London: Walter Scott Press, 1893); Angus McLaren, Our Own Master Race: Eugenics in Canada, 1885-1945 (Toronto: McClelland \& Stewart, 1990), 17. 
6 Fred Matthews, "In Defense of Common Sense: Mental Hygiene as Ideology and Mentality in Twentieth-Century America," Prospects: An Annual of American Cultural Studies 4 (1979): 474.

7 Sol Cohen, "The Mental Hygiene Movement, the Commonwealth Fund, and Public Education, 1921-1933," in Private Philanthropy and Public Elementary and Secondary Education: Proceedings of the Rockefeller Archive Center Conference, June 1979, ed. Gerald Benjamin (North Tarrytown, NY: Rockefeller Archive Center, 1980), 33-46.

8 Margo Horn, Before It's Too Late: The Child Guidance Movement in the United States, 1922-1945 (Philadelphia: Temple University Press, 1989).

9 Kathleen W. Jones, Taming the Troublesome Child: American Families, Child Guidance, and the Limits of Psychiatric Authority (Cambridge, MA: Harvard University Press, 1999).

10 Richardson, The Century of the Child, 87-108.

11 Joseph M. Hawes, Children Between the Wars: American Childhood, 1920-1940 (New York: Twayne Press, 1997), 69-70.

12 McLaren, Our Own Master Race: Dr. C. K. Clarke: 30, 56-57, 110; Dr. Oswald C. J. Withrow: 82-83; Dr. Clarence M. Hincks: 109-10.

13 C. K. Clarke, "The Fourth Maudsley Lecture," Public Health Journal 14, no. 12 (December 1923): 536.

14 Mona Gleason, Normalizing the Ideal: Psychology, Schooling and the Family in Postwar Canada, (Toronto: University of Toronto Press, 1999), 27-28.

15 Ian Robert Dowbiggin, Keeping America Sane: Psychiatry and Eugenics in the United States and Canada, 1880-1940 (Ithaca, NY: Cornell University Press, 1997), 161-162.

16 Amy Samson, "Eugenics in the Community: Gendered Professionals and Eugenic Sterilization in Alberta, 1928-1972," Canadian Bulletin of Medical History 31, no. 1 (2014): 152, 154, 158-59.

17 Jana Grekul, Harvey Krahn, and David Odynak, "Sterilizing the 'Feebleminded': Eugenics in Alberta, Canada, 1929-1972," Journal of Historical Sociology 17, no. 4 (2004): 358-84; Jana Marie Grekul, "A Well-Oiled Machine: Alberta's Eugenics Program, 1928-1972," Alberta History 59, no. 3 (Summer 2011): 16-23.

18 Donald Elroy Orn, "An Analysis of the Role of the Alberta Guidance Clinic in Edmonton” (MA thesis, University of Alberta, 1968), 1-156.

191890 Reformatory Act — Province of British Columbia, https://www2.gov.bc.ca/gov/ content/justice/criminal-justice/corrections/about-us/history/youth/1890.

20 "An Act for Establishing a Juvenile Reformatory, 1890," Revised Statutes of British Columbia, Second Report, 1897 (Victoria: Queen's Printer, 1897), J37-J40.

21 "Police and Prisons Report: Juvenile Reformatory Report," Sessional Papers of British Columbia, 1898, Fourth Session, Seventh Parliament of the Province of British Columbia, Session 1898 (Victoria: Queen's Printer, 1898), 670-72.

22 Marilyn Callahan and Christopher Walmsley, "Rethinking Child Welfare Reform in BC, 1900-60," in People, Politics, and Child Welfare in British Columbia, ed. Leslie T. Foster and Brian Wharfs (Vancouver: UBC Press, 2002), 14.

23 Tamara Myers, "Nocturnal Disorder and the Curfew Solution: A History of Juvenile Sundown Regulations in Canada," in Lost Kids: Vulnerable Children and Youth in Twentieth-Century Canada and the United States, ed. Mona Gleason, Tamara Myers, Leslie Paris, and Veronica Strong-Boag (Vancouver: UBC Press, 2010), 97.

24 Callahan and Walmsley, "Rethinking Child Welfare Reform in BC, 1900-60," 11-13.

25 "History of Youth Corrections," Province of British Columbia, https://www2.gov.bc.ca/ gov/content/justice/criminal-justice/corrections/about-us/history/youth.

26 Diane L. Matter, "The Boys Industrial School: Education for Juvenile Offenders," in Schooling and Society in 20th Century British Columbia, ed. J. Donald Wilson and David C. Jones (Calgary: Detselig, 1980), 53-70; Alistair Glegg, "Margaret Bayne and 
the Vancouver Girl's Industrial School," Historical Studies in Education/Revue d'histoire de l'éducation 18, no. 2 (2006): 201-23; Paul W. Bennett, "Taming Bad Boys of the Dangerous Class: Child Rescue and Restraint at the Victoria Industrial School, 1887-1935," Histoire sociale/Social History 21 (May 1988): 73-74.

27 Neil Sutherland, "Social Policy, 'Deviant Children' and the Public Health Apparatus in British Columbia Between the Wars," Journal of Educational Thought 14, no. 2 (August 1980): 81-83, 88.

28 Mona Gleason, “Lost Voices, Lost Bodies?' Doctors and the Embodiment of Children and Youth in English Canada from 1900 to the 1940s," in Lost Kids: Vulnerable Children and Youth in Twentieth-Century Canada and the United States, ed. Mona Gleason, Tamara Myers, Leslie Paris, and Veronica Strong-Boag, 140.

29 Helen MacMurchy, "The Relation of Feeble-mindedness to Other Social Problems," Proceedings of the National Conference on Charities and Correction (Chicago: Hildmann Printing Company, 1916), 229-35.

30 Diane Louise Janowski Matters, "'A Chance to Make Good': Juvenile Males and the Law in Vancouver, BC, 1910-1915” (MA thesis, University of British Columbia, 1978), 118.

31 Report of the First Annual Convention of the Child Welfare Association (December 12, 13, 14, 1918) (Vancouver: Grandview Printers, 1919). For Lindley, see Gerald Thomson, Remove from Our Midst These Unfortunates (PhD diss., University of British Columbia, 1999), 209-52.

32 Nic Clarke, "Sacred Daemons: Exploring British Columbian Society's Perceptions of 'Mentally Deficient' Children, 1870-1930," BC Studies 144 (Winter 2014/15): 79, 82.

33 Harry Manuel Shulman, "Intelligence and Delinquency," Journal of Criminal Law and Criminology 763 (1950-51): 769. Shulman shows that 50 per cent of delinquents were labelled feeble-minded from 1910-14, but by 1925-28, this had declined to 20 per cent.

34 Clarke, "Scared Daemons," 86-87.

35 Josephine Dauphinee, "An Appeal for the Feeble-Minded," Western Women's Weekly 1 (January 1918), 2-3.

36 "[Bertha Winn] Discusses Problem of Mental Defectives," Daily Colonist, March 21, 1917, 7.

37 Richard James Clark, "Care of the Mentally Ill in British Columbia" (MA thesis, University of British Columbia, 1947), 36.

38 For Canada, see Veronica Strong-Boag, "'Forgotten People of All the Forgotten': Children with Disabilities in English Canada from the Nineteenth Century to the New Millennium," in Lost Kids: Vulnerable Children and Youth in Twentieth-Century Canada and the United States, ed. Mona Gleason, Tamara Myers, Leslie Paris, and Veronica Strong-Boag, 40-41. For the United States, see Katrina Jirik, "Training Schools for the Feeble-Minded," Eugenics Archives, https://eugenicsarchives.ca/discover/ tree/535eee797095aa000000025f.

39 Ken Scott, "Society, Place, Work: The BC Public Hospital for the Insane, 1872-1902," Research Note, BC Studies 171 (Autumn 2011): 95-100.

40 Final Report of the Royal Commission on Mental Hygiene (Victoria: Charles F. Banfield, 1928); McLaren, Our Own Master Race, 96-99, 103-05; "Sterilization Lauded by Doctors," Vancouver Daily News, April 3, 1933, 1, 8.

41 McLaren, Our Own Master Race, 163.

42 "Treatment of Insane Here Disgraceful, Doctors Tell Investigating Commission," Victoria Daily Times, April 16, 1926, 1-2; McLaren, Our Own Master Race, 97.

43 Bulletin of the Vancouver Medical Association 5, no. 4 (January 1929): 75-76.

44 Clark, "Care of the Mentally Ill in British Columbia," 59. 
45 Val Adolph, In the Context of Its Time: A History of Woodlands (Victoria: BC Ministry of Social Services, 1996), 76.

46 "Children's Mental Clinic Is Opened: Will Undertake Preventive Work-Under Government Care," Daily Province, July 16, 1932, 5; "Child Guidance Clinic," an unauthored 1950 text of a speech found in the Child Guidance Clinic (hereafter CGC) files at the Riverview Hospital Library (hereafter RVHL), 9. When the RVHL was closed, the files were sent to the BC Provincial Archives or the Riverview Historical Society; after the latter's closure in 2016, this material was placed in the City of Coquitlam Archives.

47 For the history of Essondale, see "Riverview Hospital/Essondale/Abandoned History" at https://abandonedhistoryblog.wordpress.com/2016/12/08/riverview-mental-hospital/.

48 A. M. Gee, "Dr. Arthur Lionel Crease" (Retirement Tribute, 1950), BC Sessional Papers, Department of the Provincial Secretary, Annual Report of the Mental Hospitals of the Province of British Columbia for Twelve Months Ended March 31st, 1950 (hereafter abbreviated to Mental Hospitals Report with the appropriate year), V13-V14; "Dr. Arthur Lionel Crease," in J. C. Schwartz, ed., Who's Who Among Physicians and Surgeons, vol. 1 (New York: J. C. Schwartz, 1938), 260.

49 “Dr. Arthur Lionel Crease," Obituaries, Canadian Medical Association Journal (hereafter CMAJ) 112, no. 6 (March 22, 1975): 741.

50 William A. Bryan, Administrative Psychiatry (New York: W. W. Norton, 1936), 287-305.

51 Clark, "Care of the Mentally Ill in British Columbia," 86.

52 "Health of Children Basis of Addresses: Home and School Council Told of Need for Training," Globe, January 19, 1928, 16.

53 J. Kilburn, "The Home Adjustment of the Problem Child," Canadian Public Health Journal 20, no. 9 (September 1929): 437-38.

54 Clark, "Care of the Mentally Ill in British Columbia," 88.

55 "Children's Mental Clinic Is Opened," Daily Province, July 16, 1932, 5; "Child Guidance Clinic," RVHL, 10.

56 Clark, "Care of the Mentally Ill in British Columbia," 87-88.

57 Hawes, Children Between the Wars, 69-70.

58 Ernest Geoffrey Glover, "Case Work Interviewing Methods in a Child Guidance Setting: An Analysis Based on Records of Privately Referred Cases for 1948-1950 in the Provincial Child Guidance Clinic at Vancouver" (MA thesis, University of British Columbia, 1951), 17.

59 Gerald N. Grob, "Origins of DSM-I: A Study in Appearance and Reality," American Journal of Psychiatry 148, no. 4 (April 1991): 426-27.

60 Leo Kanner, Child Psychiatry (Springfield, IL: Charles C. Thomas Press, 1935). For a history of the field, see David M. Levy, "Orthopsychiatry: Its History, its Future-Beginnings of the Child Guidance Movement," American Journal of Orthopsychiatry 38, no. 5 (October 1968): 799-804.

61 Lewis M. Terman and Maude A. Merrill, Measuring Intelligence: A Guide to the Administration of the New Revised Stanford-Binet Test of Intelligence (Boston: Houghton Mifflin, 1937), 20-28.

62 Adolph, In the Context of Its Time: A History of Woodlands, 76.

63 Josephine F. Kilburn, "Report of the Child Guidance Clinic," BC Sessional Papers, Department of the Provincial Secretary, Mental Hospitals Report, 1932-33, L15-L16.

64 University of British Columbia calendar (1930-31), 115, 122-23. For Kerr, see Gerald Thomson, "So Many Clever, Industrious and Frugal Aliens: Peter Sandiford, Intelligence Testing, and Anti-Asian Sentiment in Vancouver Schools between 1920 and 1939," BC Studies 197 (Spring 2018): 67-100.

65 William Castle, Genetics and Eugenics: A Textbook for Biology Students (Cambridge, MA: Harvard University Press, 1916, 1920, 1924, 1930); the chapter on eugenics is "The Possibility and Prospects of Breeding a Better Human Race," 388-405. 
66 University of British Columbia calendar (1930-1931), 162; Wilfred Trotter, Instincts of the Herd in Peace and War (New York: MacMillan, 1919).

67 University of British Columbia calendar (1932-33), 169-170; Charles Spearman, The Abilities of Man (London: Macmillan, 1929); Frank Freeman, Mental Tests (New York: Houghton Mifflin, 1926); Lewis Terman, Terman Group Test of Mental Ability (London: G. G. Harrap, 1920).

68 Eric Damer, "Teaching Teachers Revisited: UBC and Educational Leadership in the 1920's," British Columbia History 44, no. 1 (Spring 2010): 39-40.

69 Clark, "Care of the Mentally Ill in British Columbia," 121.

70 University of British Columbia calendar (1930-31), arts and science student lists; University of British Columbia calendar (1931-32), social service student lists; University of British Columbia calendar (1932-33), social service student lists.

71 Callahan and Walmsley, "Rethinking Child Welfare Reform in British Columbia, 1900-60," 20, 257.

72 Josephine F. Kilburn, "Report of the Child Guidance Clinic," Mental Hospitals Report, 1933-34, Q15-Q16.

73 Josephine F. Kilburn, "Social Service Report - Victoria Child Guidance Clinic_-Provincial Child Guidance Clinic," Mental Hospitals Report, 1934-35, X14-X19.

74 Josephine F. Kilburn, “Child Guidance Clinic," Mental Hospitals Report, 1935-36, V16-V17.

75 Josephine F. Kilburn, "Provincial Government Psychiatric Clinic-Social Service Workers Clinical Work," Mental Hospitals Report, 1936-37, FF17-FF20.

76 Josephine F. Kilburn, "Social Services Report-Child Guidance Clinic," Mental Hospitals Report, 1937-38, V18-V20.

77 J. F. Kilburn, "Child Guidance Clinic," Mental Hospitals Report, 1938-39, X17-X19.

78 Melissa Suzuki, "The Kilburn Connection: Public Health Nursing Education and the Child Guidance Clinics in British Columbia, 1932-1950" (MA thesis, Trinity Western University, 2013), 61, 64-65.

79 Josephine F. Kilburn, "Social Service Report - Victoria Child Guidance Clinic-Provincial Child Guidance Clinic,” Mental Hospitals Report, 1934-35, X19.

80 Alexandra Minn Stern, Eugenic Nation: Faults and Frontiers of Better Breeding in Modern America (Berkeley: University of California Press, 2005), 18-19.

81 McLaren, Our Own Master Race, 163, 161, chapter 8, note 65. McLaren found only a letter from the Provincial Eugenics Board referencing the files of the Child Guidance Clinic, not actual clinic patient files. BC Archives, Mental Health Services, GR542, box 14. An e-mail to McLaren confirmed that he never found any patient files for the Child Guidance Clinic while researching Our Own Master Race.

82 Clark, "Care of the Mentally Ill in British Columbia," 95-97.

83 Josephine F. Kilburn, "Child Guidance Clinic," Mental Hospitals Report, 1940-41, N19-N20.

84 Josephine F. Kilburn, “Child Guidance Clinic,” Mental Hospitals Report, 1941-42, Y19-Y21.

85 Kilburn, "Child Guidance Clinic," Mental Hospitals Report, 1941-42, Y20.

86 Josephine F. Kilburn, "Child Guidance Clinic," Mental Hospitals Report, 1942-43, T22-T23.

87 Clark, "Care of the Mentally Ill in British Columbia," 88.

88 Josephine F. Kilburn, "Child Guidance Clinic," Mental Hospitals Report, 1944-45, GG22-GG23.

89 Josephine F. Kilburn, "Child Guidance Clinic," Mental Hospitals Report, 1944-45, GG22; J. F. Kilburn, "Child Guidance Clinics," Mental Hospital Report, 1938-39, X18.

90 Josephine F. Kilburn, "Child Guidance Clinics," Mental Hospitals Report, 1945-46, $\mathrm{HH} 22$. 
91 "Ultan P. Byrne, M.D., D.P.H., 455 West 13th Avenue, Vancouver, B.C., Canada. Director of Clinics, Psychopathic Division, Provincial Mental Hospitals" in "Association News," American Journal of Public Health 37, no. 2 (February 1947): 231; "Dr. Ultan Patrick Byrne," Obituaries, CMAJ 81, no. 9 (November 1, 1959): 771; Wrigley's British Columbia Directory 1928, 1931, "Essondale," 286, 256; British Columbia and Yukon Directory 1935, 1939, "Essondale," 501, 122; Byrne Family Collection Fonds, BHS316, MSS141, Burnaby City Archives, https://search.heritageburnaby.ca.

92 Ultan P. Byrne, "Child Guidance Clinics," Mental Hospitals Report, 1945-46, $\mathrm{H} 24-\mathrm{H} 26$.

93 Ultan P. Byrne, "Child Guidance Clinics," Mental Hospitals Report, 1946-47, S24-S27.

94 Suzuki, The Kilburn Connection, 51-53; J. F. Kilburn, "Psychiatric Social Worker's Participation in Child Guidance Clinic Services," Mental Hospitals Report, 1946-47, S27-S28.

95 "Dr. Ultan Patrick Byrne," Obituaries, CMAJ 81, no. 9 (November 1, 1959): 771.

96 Arthur L. Crease, "Report of the Medical Superintendent," Mental Hospitals Report, 1944-45, GG11, and Mental Hospitals Report, 1948-49, BB13. For the Second World War and psychiatry, see Grob, "Origins of DSM-I," 427-28.

97 British Columbia and Yukon Directory 1944-1948 and Vancouver and New Westminster City Directory 1949-1955 showed Dr. Ultan P. Byrne living at 905 12th Street, New Westminster.

98 Grob, “Origins of DSM-I," 426-27, 428.

99 GR-0133, Mental Health Services, BC Archives, executive records, 1936-72, 1, https:// search-bcarchives.royalbcmuseum.bc.ca/Document/Finding_Aids_Atom/GR-0001_To_ GR-0500/gr-0133.pdf; A. L. Crease, "Report of the Medical Superintendent," Mental Hospital Report, 1947-48, BB10-BB11.

100 Clark, "Care of the Mentally Ill in British Columbia," 50, 93-94. Chlorpromazine (Thorazine) was the first psychotropic drug; see Peter Haddad, Robert Kirk, and Richard Green, "Chlorpromazine: The First Antipsychotic Medication," British Association for Psychopharmacology (October 2016): 1-3.

101 Madeleine P. Strohl, "Bradley's Benzedrine Studies in Children with Behavioral Disorders," Yale Journal of Biology and Medicine 84 (2011): 27-33.

102 “Dr. Ultan Patrick Byrne," Obituaries, CMAJ 81, no. 9 (November 1, 1959): 771.

103 Ultan P. Byrne, "Child Guidance Clinics," Mental Hospitals Report, 1947-48, BB22-BB28.

104 Gerald Thomson, "Not an Attempt to Coddle Children: Dr. Charles Hegler Gundry and the Mental Hygiene Division of the Vancouver School Board, 1939-1969," Historical Studies in Education/Revue d'histoire de l'éducation 14, no. 2 (2002): 261-62.

105 Ultan P. Byrne, "Child Guidance Clinics," Mental Hospitals Report, 1948-49, $\mathrm{HH} 28-\mathrm{HH} 35$.

106 For the ICD Revision 6 (1948), see www.wolfbane.com>icd>icd6h. The first DSM-I or Diagnostic and Statistical Manual of Mental Disorders would not be published until 1952. For the integration of children's mental disorders into the DSM-I, see www. kidsandmeds.umwblogs.org/dsm1/.

107 Accessed as unauthored draft copies of speeches/talks given by staff of the provincial Child Guidance Clinic as found in the CGC files at the RVHL. See note 46 for details about the disposition of this material after RVHL's closure.

108 "The Normal Child" (1946), CGC files RVHL, 2.

109 "Hetrosexual Interests and Activities" (1946), CGC files RVHL, 2, 6.

110 Carolyn Strange and Jennifer A. Stephen, "Eugenics in Canada: A Checkered History, 1850s-1900s," in The Oxford Handbook of the History of Eugenics, ed. Alison Bashford and Phillippa Leveine (New York: Oxford University Press, 2010), 527-28.

111 "The Family and the Home" (1947), CGC files, RVHL, 1. For Paul Popenoe, see Stern, Eugenic Nation, 156-64. 
112 "Preschool Development" (1948), CGC files, RVHL, 3.

113 "Child Guidance Clinic" (1947), CGC files, RVHL, 6.

114 "The Role of the Child Guidance Clinic in a Mental Hygiene Program" (1946), CGC files, RVHL, 2-4.

115 Evelyn Marie Roberts, "Mental Health Clinical Services: A Study of the Children Between 6 and 12 Years of Age Examined by Mental Health Clinics in Vancouver from 1945 to 1947 Inclusive" (MA thesis, University of British Columbia, 1949), 39, 47, $51-52,63,113,123$.

116 Ultan P. Byrne, transcript of a radio talk given at Penticton, May 18, 1950, CGC files, RVHL, 3. In 1952, a parents' committee headed by Mrs. Purdy opened a day school for mentally handicapped children at St. Michael's Anglican Church, Vancouver. Help was provided by the Child Guidance Clinic and eventually the Oakridge School for Retarded Children opened in 1961. See https://www.develop.bc.ca/drive/ uploads/2017/11/dda-history.pdf.

117 Ultan P. Byrne, "Retarded Child," transcript of a speech given to the Essondale Summer School of Nursing, July 26, 1950, CGC files, RVHL, 3, 5, 7.

118 Ultan P. Byrne, "Emotional, Intellectual, Character, Social and Physical Needs," 1951, CGC files, RVHL, T5.

119 See in the Mental Hospitals Report, 1949-50: A. L. Crease, "Report of the Director of Mental Hygiene," V19, and Ultan P. Byrne, "Child Guidance Clinics," V36-V44.

120 Ultan P. Byrne, "Reports of the Child Guidance Clinics - Director," Mental Health Services Report, 1950-51, O78-O85.

121 For Dr. Guy Richmond/Heritage Burnaby, see https://search.hertiageburnaby. ca.>archive; interview with Guy Richmond, BC Archives, AAAB2558 (1976-02-26).

122 Ultan P. Byrne, "Reports of the Child Guidance Clinics - Report of the Director," Mental Health Services Report, 1951-52, Q91-Q99.

123 Ultan P. Byrne, "Reports of the Child Guidance Clinics - Report of the Director," Mental Health Services Report, 1952-53, T106-T117.

124 Donald B. Ricketts, "Social Services Department," Mental Health Services Report, 1952-53, T113-T114.

125 See in the Mental Health Services Report, 1952-53: Marjory Munroe, "Psychology Department," T116; Ultan P. Byrne, "Reports of the Child Guidance Clinics - Report of the Director," T106-T112.

126 See in the Mental Health Services Report, 1953-54: Ultan P. Byrne, "Child Guidance Clinics - Report of the Director," R236-R242; Donald B. Ricketts, "Social Service Department," R242-R245; Marjory Munro, "Psychology Department,” R246-R247; Table No. 3, Case Referrals, R239.

127 Ultan P. Byrne, "Child Guidance Clinics - Report of the Director," Mental Health Services Report, 1954-55, M199.

128 1950s: The Brannan Lake Industrial School and Willingdon Industrial School, https://www.2.gov.bc.ca/gov/content/justice/corrections/about-us/history/youth/1950

129 See in the Mental Health Services Report, 1954-55: Ultan P. Byrne, "Child Guidance Clinics - Report of the Director," M199-M205; Marjorie Munro, "Psychology Department," M209-M211; and Robert Macdonald, "Social Service Department," M206-M209.

130 "New Child Guidance Centre, Mental Clinic, for Burnaby," Vancouver Sun, June 30, 1954, 18.

131 Ultan P. Byrne, "Child Guidance Clinics - Report of the Director," Mental Health Services Report, 1954-55, M201.

132 “\$1 Million Centre for Children," Vancouver Province, June 30, 1954, 17; “Cost Will Be about \$1,000,000," Vancouver Province, July 7, 1954, 16. 
133 See in the Mental Health Services Report, 1955-56: Ultan P. Byrne, "Child Guidance Clinics - Report of the Director," Q208-Q217; D. B. Ricketts, "Social Service Department,” Q217-Q220; and M. Munro, "Psychology Department,” Q221-Q223.

134 "Child Guidance Clinic and Mental Health Centre-Open House, May 1st, 1957," souvenir pamphlet from GR-2720.2.1, G91-015, box 2, file 1, BC Archives.

135 See in the Mental Health Services Report, 1956-57: Ultan P. Byrne, "Child Guidance Clinics - Director's Report," Q215-Q223; D. B. Ricketts, "Social Service Department," Q224-Q225; and M. Munro, "Psychology Department,” Q225-Q227.

136 Nell Wilson Freer, "Brief Service in a Child Guidance Clinic: A Preliminary Survey" (MA thesis, University of British Columbia, 1957), 1-39.

137 Ernest Geoffrey Glover, "Casework Interviewing Methods in a Child Guidance Setting" (MA thesis, University of British Columbia, 1951); Budd Mackenzie, "The Play Interview as a Social Work Technique in a Child Guidance Clinic" (MA, University of British Columbia, 1956); Ramona Kennedy, "Initial Resistance of Parents to Casework Services in a Child Guidance Setting" (MA thesis, University of British Columbia, 1957); L. W. Laidman, "Premature Withdrawal from Treatment in a Child Guidance Clinic" (MA, University of British Columbia, 1957).

138 Ulan P. Byrne, "Child Guidance Clinics - Director's Report," Mental Health Services Report, 1957-58, L129-L139.

139 F. E. McNair and U. P. Byrne, "The Mental Health Centre and the Child Guidance Clinic Burnaby, British Columbia," Psychiatric Services 9, no. 7 (September 1958): 37-43.

140 Purdue University, "Finding Aid to the Hollywood Hospital Program and Lecture Notes, 1959." Two files contain notes by Dr. Byrne: folder \#3, "Practical Evaluation of LSD-25 at the Present Time," and folder \#10, "Some Newer Drugs Used in Psychiatric Practice." The papers are published online at collections.lib.purdue.edu/fa/pdf/ hollywood_hospital.pdf. See also J. Ross Maclean, D. C. MacDonald, Ultan P. Byrne, and A. M. Hubbard, "The Use of LSD-25 in the Treatment of Alcoholism and Other Psychiatric Problems," Quarterly Journal of Studies on Alcohol 22 (1961): 34-45.

141 “Dr. Ultan Patrick Byrne," CMAJ 81, no. 9 (November 1, 1959), 771.

142 Margaret A. Ormsby, British Columbia: A History (Toronto: Macmillan, 1958), 491.

143 "Essondale Woodlands Hit: Social Workers see 'Chaos' in Gov't Staff Cuts," Vancouver Sun, January 17, 1958, 1.

144 "Sun Reporter Sees Empty Beds in Woodlands," Vancouver Sun, January 29, 1953, 3.

145 "Socred, CCfers Hit Institution Slashes," Vancouver Sun, January 29, 1958, 3.

146 "The Clock Turns Back: Explanation Demanded for Dismantling Social Services," Vancouver Sun, January 29, 1958, 4.

147 “\$13,000,000 Trimmed Off B.C.’s Budget,” Vancouver Sun, February 7, 1958, 1.

148 "Bennett Budget Lops Off 700 Jobs," Vancouver Sun, February 8, 1958, 1-2.

149 "Mental Hospitals' 'Increasing Burden', Vancouver Sun, February 12, 1958, 17.

150 "Ban Lifted on Mental Hospitals," Vancouver Sun, February 13, 1958, 1; "Bonner Relents: Borstal Saved," Vancouver Sun, February 13, 1958, 25; "Doctors Attack Black for Mental Hospitals Report," Vancouver Sun, February 14, 1958, 1.

151 “Child Guidance Cuts 'Disgraceful'," Vancouver Sun, February 14, 1958, 7.

152 “B.C. Mental Health Services Near Crisis," Vancouver Sun, February 18, 1958, 4.

153 “Essondale's New Buildings Idle," Vancouver Sun, February 18, 1958, 1.

154 Josephine F. Kilburn, "Child Guidance Clinic," Mental Hospitals Report, 1941-42, Y20.

155 K. J. Davies, "Mental Health Centre Director's Report," Mental Health Services Report, 1962-63, D145, D148. 